\title{
A dynamic and thermodynamic analysis of the 11 December 2017 tornadic supercell in the Highveld of South Africa
}

\author{
Lesetja E. Lekoloane ${ }^{1,2}$, Mary-Jane M. Bopape ${ }^{1}$, Tshifhiwa Gift Rambuwani ${ }^{1}$, Thando Ndarana ${ }^{3}$, \\ Stephanie Landman ${ }^{1}$, Puseletso Mofokeng ${ }^{1,4}$, Morne Gijben ${ }^{1}$, and Ngwako Mohale ${ }^{1}$ \\ ${ }^{1}$ South African Weather Service, Pretoria, 0001, South Africa \\ ${ }^{2}$ Global Change Institute, University of the Witwatersrand, Johannesburg, 2050, South Africa \\ ${ }^{3}$ Department of Geography, Geoinformatics and Meteorology, University of Pretoria, Pretoria, 0001, South Africa \\ ${ }^{4}$ School of Geography, Archaeology and Environmental Studies, University of the Witwatersrand, \\ Johannesburg, 2050, South Africa
}

Correspondence: Lesetja E. Lekoloane (lesetja.lekoloane@weathersa.co.za)

Received: 28 July 2020 - Discussion started: 3 August 2020

Revised: 16 February 2021 - Accepted: 19 February 2021 - Published: 28 April 2021

\begin{abstract}
On 11 December 2017, a tornadic supercell initiated and moved through the northern Highveld region of South Africa for $7 \mathrm{~h}$. A tornado from this supercell led to extensive damage to infrastructure and caused injury to and displacement of over 1000 people in Vaal Marina, a town located in the extreme south of the Gauteng Province. In this study we conducted an analysis in order to understand the conditions that led to the severity of this supercell, including the formation of a tornado. The dynamics and thermodynamics of two configurations of the Unified Model (UM) were also analysed to assess their performance in predicting this tornadic supercell. It was found that this supercell initiated as part of a cluster of multicellular thunderstorms over a dry line, with three ingredients being important in strengthening and maintaining it for $7 \mathrm{~h}$ : significant surface to midlevel vertical shear, an abundance of low-level warm moisture influx from the tropics and Mozambique Channel, and steep mid-level lapse rates. It was also found that the $4.4 \mathrm{~km}$ grid spacing configuration of the model (SA4.4) performed better than the $1.5 \mathrm{~km}$ grid spacing version. SA1.5 underestimated the low-level warm moisture advection and convergence, and missed the storm initiation. SA4.4 captured the supercell; however, the mid-level vorticity was found to be 1 order of magnitude smaller than that of a typical mesocyclone. A grid length of $4.4 \mathrm{~km}$ is too coarse to fully capture the details of a mesocyclone, which may also explain why the model underestimated the surface to mid-level wind shear and low-level horizontal mass and moisture flux con-
\end{abstract}

vergence. Future investigations will involve experimental research over the Highveld region of South Africa to understand mesoscale and local dynamics processes responsible for tornadogenesis in some severe storms. Such a study, to the best of our knowledge, has never been conducted.

\section{Introduction}

Human survival and development are directly and indirectly impacted by weather and climate extremes (Nuttall, 1998; IPCC, 2014). In their different spatial and temporal scales and reach, extreme weather events can result in prolonged negative socio-economic impacts and affect different facets of the society, including ecosystems (Meehl et al., 2000). Examples of these extremes include powerful synoptic tropical systems such as Tropical Cyclone Eline (Reason and Keibel, 2004) and Tropical Cyclone Idai (WMO, 2019) that occurred in the years 2000 and 2019, respectively. These severe storms affected millions of people in the southern African mainland. Extreme weather events have been observed in other parts of the world, for instance the unusually extended tornado outbreak that occurred across the central and eastern United States during May 2003 and resulted in about USD 829 million of property damage (Hamill et al., 2005). There is growing evidence suggesting that these extreme events are becoming more common across the globe and can be expected to in- 
crease in intensity and frequency due to climate change (e.g. Handmer et al., 2012; Melillo et al., 2014; EASAC, 2018).

There is no region on Earth immune to extreme or severe weather events, but the most vulnerable communities are especially those from developing countries (Mirza, 2003). For example, many developing countries' economies and livelihoods are highly dependent on primary sectors of the economy (UN, 2018a) such as agriculture and fishing, the negative effects of which have already been experienced due to an increase in high-impact weather events (Adger et al., 2003; Awojobi and Tetteh, 2017). Therefore, an understanding of these high-impact weather events, and being able to predict them precisely, is of importance for sustainable development as well as mitigation and adaptation strategies.

One of the regions identified as highly vulnerable to climate change and its effects is sub-Saharan Africa (Boko et al., 2007). Most countries in this region of the world are lacking behind in the development scale (Carley and Bustelo, 1986) and have many stressors including highimpact weather events (UN, 2018b). Although no single weather event can be confidently attributed to climate change, an increasing number of studies are documenting a positive trend of severe weather events in southern Africa (Davis-Reddy and Vincent, 2017; Kruger and Nxumalo, 2017). These include an increase in the frequency of extreme rainfall events associated with land-falling tropical cyclones and severe thunderstorms, particularly in the eastern parts of southern Africa and south of South Africa (Malherbe et al., 2013; Engelbrecht et al., 2013).

A climatological analysis over South Africa indicates an increase in extreme rainfall events, especially during spring and summer months (Engelbrecht et al., 2013; DEA, 2016) mostly in the form of convective precipitation (Tyson and Preston-Whyte, 2000; Hart et al., 2013). The eastern parts of South Africa are dominated by thunderstorms during summer months which often result in fatalities, serious injuries, and extensive damage to infrastructure including crops and livestock (Gijben, 2012; NDMC, 2018).

Thunderstorms are primarily classified either as single cell, multicell, or supercell - all three types could become very severe and destructive, with supercell thunderstorms notoriously known for producing spectacular tornadoes (Houze, 1993). It should be noted that some multicell thunderstorms can also produce tornadoes (including non-mesocyclonic tornadoes) and that not all supercell thunderstorms produce tornadoes (Markowski and Richardson, 2009). Tornadoes are common around the world, but the most severe are often reported in the United States of America (e.g. Hamill et al., 2005).

South Africa experiences a significant number of severe thunderstorms annually, especially during summer months over the Highveld (Gijben, 2012). A few of these intensify to severe supercell type and often result in strong damaging winds, large hail, and tornadoes (Rae, 2014; Glickman, 2000). Tornadoes can occur anywhere in South Africa, but they are frequently reported in the Highveld regions of Gauteng, north-eastern Free State, western Mpumalanga, and south-central KwaZulu Natal (Goliger and Retief, 2007).

Research has shown that the possible two main important factors for the initiation of tornadoes in thunderstorms are large amounts of low-level water vapour and the presence of boundary layer vertical wind shear (Markowski and Richardson, 2009). A recent study by Dahl (2017) has shown that the tilting of horizontal vorticity alone is not enough to produce a rotating updraught in supercells. For the tilting of horizontal vorticity, a downdraught is needed possibly at the rear flank of the storm to pair the updraught in the inflow side of the storm (Davies-Jones et al., 2001). However, this downdraught is not necessary if near-surface vertical vorticity preexisted before the storm genesis, in which case near-surface convergence alone is enough for tornadogenesis (Markowski and Richardson, 2009). Davies-Jones (2015) has summarised tornadogenesis in supercells as occurring in three stages: the formation of mesocyclone in the mid-level, rotation at the ground, and tornado formation or failure.

On 11 December 2017, a supercell thunderstorm associated with large hail, strong damaging winds, and a tornado tracked through Vaal Marina, a town in the extreme south of the Gauteng Province of South Africa. The tornadic supercell led to trees being uprooted, destroyed commercial and residential properties, and left about 50 people injured and over 1100 informal settlement dwellers displaced (SAWS, 2018). The aim of this study is to perform an analysis of this supercell in order to understand the conditions that led to its severity, including the formation of a tornado in Vaal Marina. The dynamics and thermodynamics of two configurations of a numerical weather prediction (NWP) model operationally run at the South African Weather Service (SAWS) are also analysed and evaluated to see how they performed in predicting this tornadic supercell.

NWP has advanced over the years (Bauer et al., 2015), with current NWP models operating in the convectionpermitting scale where convection schemes are switched off or restricted (Clark et al., 2016). A numerical modelling study by Weisman et al. (1997) found that a $4 \mathrm{~km}$ model grid spacing may be sufficient to reproduce mesoconvective circulations and net momentum and heat transport of midlatitude-type convective systems. With this understanding the super-parameterisation modelling procedure was developed with most of the embedded cloud-resolving models running with a grid length of $4 \mathrm{~km}$ (Randall et al., 2003, 2016). Other studies, however, argue that models of grid spacing of $1 \mathrm{~km}$ or less are the ones adequate to represent dynamics and local processes responsible for triggering convection (see Roberts, 2008; Bryan et al., 2003). In this study, we consider a model run with a grid length of 4.4 and $1.5 \mathrm{~km}$. 


\section{Data and methods}

\subsection{Area of interest}

The focus area of this study is in the northern parts of the Highveld region of South Africa and covers Vaal Marina located in the extreme south of the Gauteng Province and the storm track in the Free State and Mpumalanga provinces as shown in Fig. 1. The locations of SAWS radars used to track the storm of interest and weather stations where data were analysed for mesoscale circulations, in this study, are also shown. The storm track as shown in Fig. 1 was identified and reproduced using the Thunderstorm Identification, Tracking, Analysis and Nowcasting (TITAN) and QGIS software to mark geographic information system (GIS) locations of the cell for each radar scan (for both radars in Irene and Ermelo, individual and merged for validation) from initiation to dissipation of the storm.

\subsection{Datasets}

\subsubsection{The Unified Model}

The primary model data analysed in this study are from the Unified Model (UM) (version 10.4). The UM is a seamless and deterministic numerical modelling system originally developed by the United Kingdom's Meteorological Office (UKMO) for weather prediction and climate studies (Davies et al., 2005). This model is operationally run four times a day on the SAWS CRAY XC-30 high-performance computing system. Initial and boundary conditions from the Global Atmosphere (GA, Walters et al., 2017) are used as the driving data for the purpose of producing short-range operational weather forecasts of up to $3 \mathrm{~d}$ ahead.

The UM is run in two configurations of the regional and sub-regional domains with 70 vertical levels. The first configuration runs at a horizontal grid length of $4.4 \mathrm{~km}$ (this configuration is hereafter referred to as SA4.4) and covers the domain from 0 to $36^{\circ} \mathrm{S}$ and 5 to $54^{\circ} \mathrm{E}$. This setup essentially covers the Southern African Development Community (SADC) except the northern parts of the Democratic Republic of the Congo. The second configuration is centred over South Africa from 20 to $36^{\circ} \mathrm{S}$ and 15 to $34^{\circ} \mathrm{E}$ and is run at a horizontal grid length of $1.5 \mathrm{~km}$ (this configuration is hereafter referred to as SA1.5). The model configurations analysed in this study were both operationally initialised and run at 00:00 UTC on 11 December 2017.

The dynamical core of the model configurations in this study uses a semi-implicit semi-Lagrangian formulation to solve the non-hydrostatic, fully compressible deepatmosphere equations of motion (Wood et al., 2014). On the other hand, physical parameterisations of sub-grid processes are split into slow processes (radiation and microphysics) and fast processes (atmospheric boundary layer turbulence, cloud and surface coupling) which are treated and computed differently.

\subsubsection{Radiosonde, satellite, station, and radar data}

To perform an analysis of the thunderstorm and its proximal environment during its life cycle, surface weather station data and radar data are obtained from the SAWS weather station and radar networks. Surface observation data from a total of up to 228 automatic weather stations across South Africa were regridded and used for synoptic analysis. The regridding is done using the Cressman objective analysis scheme which is described in detail by Cressman (1959). The regridded surface data points are $25 \mathrm{~km}$ apart. Only a selected number of stations proximally closer to the storm track in the Free State, Gauteng, and Mpumalanga provinces were used for mesoanalysis (see Fig. 1). The surface station data used contain temperature, dew point temperature, pressure, wind speed, wind direction, and rainfall. A surface chart analysis was also performed using data from these stations.

To capture data from middle to lower levels of the storm, the Irene $\left(25.87^{\circ} \mathrm{S}, 28.22^{\circ} \mathrm{E}\right)$ and Ermelo $\left(26.53^{\circ} \mathrm{S}\right.$, $30.03^{\circ} \mathrm{E}$ ) weather radars are used to track the storm throughout its cycle, from initiation to dissipation (see Fig. 1). We also include the Integrated Multi-satellite Retrievals for Global Precipitation Measurement (GPM) (IMERG) for precipitation observation (Huffman et al., 2019).

A 12:00 UTC Irene weather office radiosonde sounding, on the day considered, is used as a proximity sounding of the atmospheric conditions at Vaal Marina. The Irene weather office is located about $110 \mathrm{~km}$ north of Vaal Marina and is therefore within the proximity sounding criteria for the location as defined by Craven and Brooks (2004). Radiosonde sounding from the Bram Fischer International Airport (FABL) in Bloemfontein was also used to capture upstream winds.

\subsubsection{Reanalysis data and synoptic analysis}

The fifth-generation reanalysis of the atmosphere (ERA5) produced by the European Centre for Medium-Range Weather Forecasts (ECMWF) on single and pressure levels is utilised to analyse meteorological conditions of the day. The ERA5 dataset is the state-of-the-art atmospheric reanalysis of the global climate with a horizontal grid length of $0.25^{\circ} \times 0.25^{\circ}$ and 137 vertical levels up to $1 \mathrm{~Pa}$ (Hersbach and Dee, 2016). Parameters analysed from this dataset include $10 \mathrm{~m}$ winds; mean sea level pressure; convective and nonconvective precipitation; and geopotential heights at 850 , 500 , and $300 \mathrm{hPa}$ levels. A surface chart analysis performed by operational forecasters at the SAWS for 12:00 UTC on 11 December 2017 is also used in the synoptic analysis and mesoanalysis.

To further analyse instability, the ERA5 dataset is used to plot and analyse the environmental lapse rate (ELR) and 


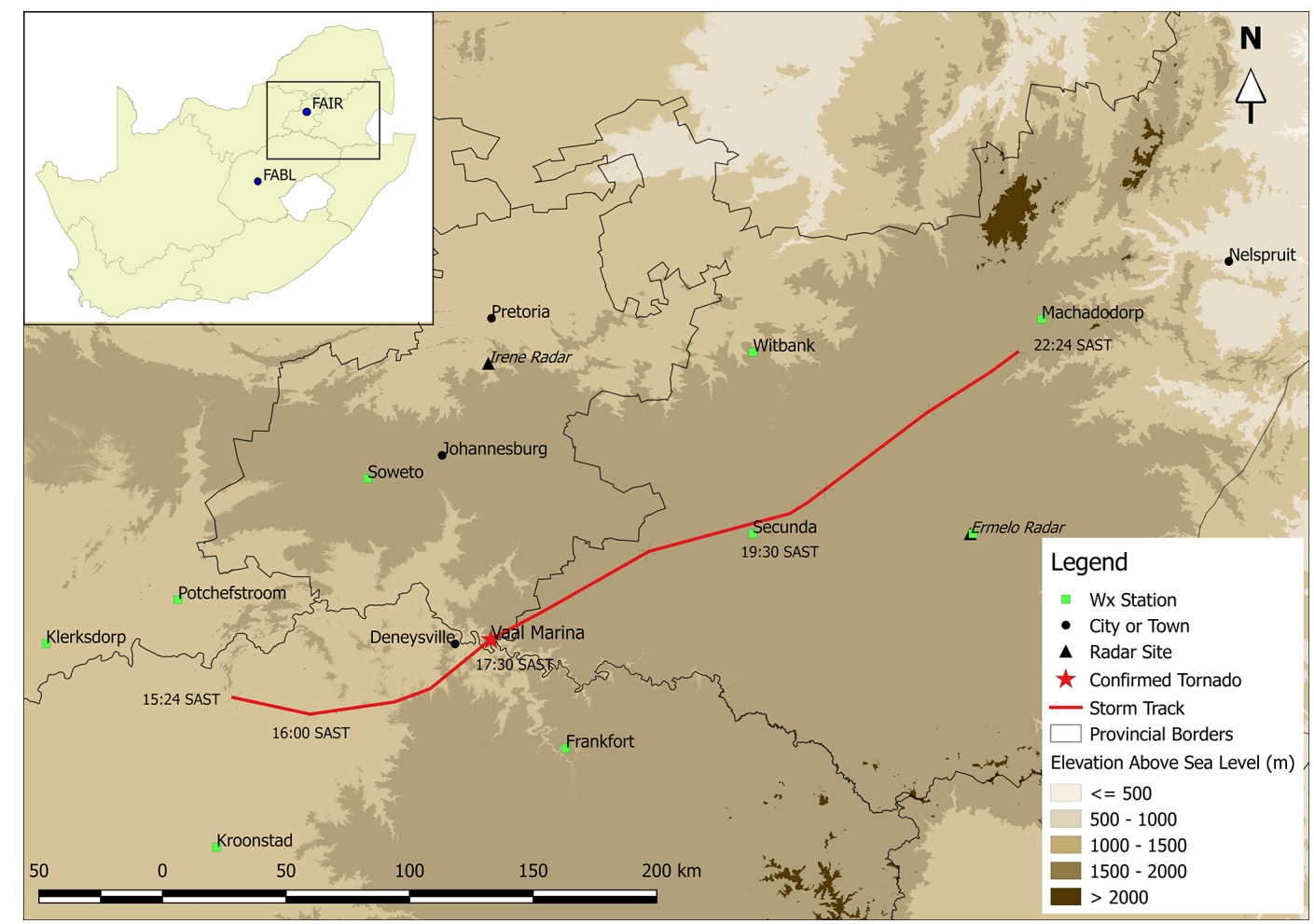

Figure 1. The map of South Africa highlighting northern parts of the Highveld (defined as enclosed by the $1500 \mathrm{~m}$ a.s.1. height). The supercell track is indicated with a red line and includes the location of the storm at local times during its $7 \mathrm{~h}$ propagation. Weather stations (Wx Stations) where surface data were analysed for mesoscale circulations are also indicated, including the location of the Vaal Marina tornado. The top left embedded image indicates locations where radiosondes analysed were released, in Irene (FAIR) and Bloemfontein (FABL).

used to supplement upper-air sounding data. ELR fields are analysed between 700 and $500 \mathrm{hPa}$, which typically represents the mid-levels of the atmosphere. The mid-level ELRs are calculated by looking at the decrease in temperature with height (Glickman, 2000) as indicated by the following equation:

$\Gamma=-\frac{\mathrm{d} T}{\mathrm{~d} z}$,

where $T$ is the temperature in degrees Celsius $\left({ }^{\circ} \mathrm{C}\right), z$ is the altitude in kilometres $(\mathrm{km})$, and $\Gamma$ is the lapse rate in ${ }^{\circ} \mathrm{Ckm}^{-1}$.

\subsubsection{Dynamic and thermodynamic analysis}

In this study, both the 4.4 and $1.5 \mathrm{~km}$ horizontal grid spacing of the model configurations are not high enough to reliably use only wind vectors as a determinant of organised mesoscale rotation. As an alternative, vorticity is used as a measure of rotation and has an added advantage in that it includes most of the flow even in our considered resolutions and is also much easier to use for rotation analysis compared to only using wind vectors (Stevens and Crum, 2003).

Vorticity is a curl of velocity and gives the measure of a fluid's infinitesimal rotation (Holton and Hakim, 2013). Ig- noring the effects of friction, the Boussinesq approximation of the vorticity equation can be written as

$$
\frac{\partial \overline{\boldsymbol{\omega}}}{\partial t}=\nabla \times(\overline{\boldsymbol{V}} \times \overline{\boldsymbol{\omega}})+\nabla \times(B \hat{k}),
$$

where $\overline{\boldsymbol{\omega}}=(\xi, \eta, \zeta)$ and $\overline{\boldsymbol{V}}=(u, v, w)$ respectively represents vorticity and velocity vectors in the horizontal $(x, y$ axis) and vertical ( $z$ axis), and $B$ is the buoyancy.

It is not uncommon for thunderstorms to rotate, with supercell thunderstorms spectacularly distinguished by an even stronger and persistent vertically rotating updraught (Doswell and Burgess, 1988; Houze, 1993). Consequently, the current study utilises the vertical component of relative vorticity $\zeta$ as a diagnostic tool of rotation in the vertical axis. It can be derived from Eq. (1) to get

$\frac{\partial \zeta}{\partial t}=\hat{k} \times \nabla \times(\overline{\boldsymbol{V}} \times \overline{\boldsymbol{\omega}})+\hat{k} \times \nabla \times(B \hat{k})$.

It should be noted from Eq. (2) that $\hat{k} \times \nabla \times(B \hat{k})=0$. This implies that buoyancy is not directly responsible for the generation of vertical vorticity and therefore vertical rotation in thunderstorms. Further simplifying Eq. (2) gives

$\frac{\partial \zeta}{\partial t}=-\overline{\boldsymbol{V}} \times \nabla \zeta+\overline{\boldsymbol{\omega}}_{\mathrm{H}} \times \nabla_{\mathrm{H}} w+\zeta \frac{\partial w}{\partial z}$, 
where the terms on the right-hand side of the equation respectively represent the advection, tilting, and stretching terms.

In this study our dynamical definition of a mesocyclone follows that of Glickman (2000), which defines it as a cyclonically rotating vortex in a thunderstorm associated with vorticity on the order of $10^{-2} \mathrm{~s}^{-1}$ or greater. The horizontal scale of this vortex is normally somewhere between 2 and $10 \mathrm{~km}$ in a thunderstorm.

To analyse the significance of low-level moisture in the event considered, the convergence of moisture flux is integrated from the surface up to $600 \mathrm{hPa}$ level. Moisture flux convergence (MFC) is a useful diagnostic tool for convection initiation as it combines the effects of moisture advection and convergence and can be computed at any atmospheric pressure level (Banacos and Schultz, 2005). The reason we integrate from the surface to $600 \mathrm{hPa}$ is because we want to capture the significance of the convergence of low-level moisture fluxes. Ndarana et al. (2021) argues that the flow associated with ridging South Atlantic anticyclones, a low-level synoptic driver in our study, changes completely beyond $600 \mathrm{hPa}$ to become sinusoidal and westerly.

To derive an equation for MFC, the conservation of water vapour is used and is further expanded and written in flux form using the continuity equation to get

$$
\frac{\partial q}{\partial t}+\nabla \times\left(q \overline{\boldsymbol{V}}_{\mathrm{h}}\right)+\frac{\partial}{\partial p}(q \boldsymbol{\omega})=S=E-P,
$$

where $q$ is the specific humidity, and the second and third terms respectively represent horizontal and vertical moisture flux divergence. $S$ represents the sources and sinks of the air parcel's water vapour evaporation rate $(E)$ and precipitation rate $(P)$, assuming that all condensed water precipitates immediately. MFC is computed by taking the negative of the horizontal moisture flux divergence in Eq. (4), which gives

$\mathrm{MFC}=-\nabla \times\left(q \overline{\boldsymbol{V}}_{\mathrm{h}}\right)$.

MFC is then integrated from the surface $\left(p_{\mathrm{s}}\right)$ to $600 \mathrm{hPa}$ and becomes

$$
\mathrm{MFC}^{*}=-\frac{1}{g} \int_{600}^{p_{\mathrm{s}}} \nabla \times\left(q \overline{\boldsymbol{V}}_{\mathrm{h}}\right) \mathrm{d} p .
$$

\section{Results and discussion}

Media reports indicated that on the late afternoon of 11 December 2017, a severe thunderstorm, which resulted in extensive damage, tracked through the extreme south of the Gauteng Province of South Africa (Mitchley, 2017). Some eyewitnesses reported seeing a tornado close to Deneysville near the Vaal Dam, which later made its way to Vaal Marina and Mamello informal settlement (all these locations are hereafter collectively referred to as VAM) (Mashaba and ANA reporter, 2017). Witnesses also reported strong, damaging winds and large hail (SABC, 2017). Visual impacts of the observed severe storm were also captured by some reports and indicate uprooted trees, damaged houses, and shacks, including damaged infrastructure such as overhead power lines (Storm Report SA, 2017). From these vast reports, it is clear that this was a high-impact weather system and is therefore important to analyse.

\subsection{Synoptic setting and meteorological conditions of 11 December 2017}

On 11 December 2017, the analysis indicates the presence of a ridging anticyclone which extended north of the south-eastern subcontinent and in the process of breaking off from the parent Atlantic anticyclone to merge with the south Indian Ocean anticyclone located east of South Africa (indicated by the letter $\mathrm{H}$ over south-west Indian Ocean, SWIO; Fig. 2d). The Atlantic anticyclone began ridging behind a cold front which moved over south of the continent between 8 and 9 December and was located southeast of the continent on 10 December. The ridging anticyclone, which was situated in the south-eastern subcontinent on 10 December, led to an influx of warm and unstable low-level moisture from SWIO through the Mozambique Channel into the eastern and central provinces of South Africa: Mpumalanga, Limpopo, Gauteng, North West, and Free State. The northward-extended, and now breaking, ridging anticyclone on 11 December was coupled with a deepened surface trough in the central interior of South Africa (indicated by the letter L over South Africa; Fig. 2d, cf. Fig. 2c), resulting in moisture level increase in the eastern half of the country due to warm tropical inflow of unstable air mass.

The analysis also indicates the presence of a midtropospheric trough over the south-east of the continent and a ridge extending over Namibia and the western parts of South Africa (Fig. 2b). This mid-level circulation pattern resulted in mid-atmospheric south-westerly winds over the interior of South Africa, which enhanced convective instability over the east-central part of the country as a result of the steep mid-level lapse rates and low-level warm and moist air in the east. This instability can clearly be seen from environmental lapse rates which are discussed in much detail in Sect. 3.2 (mesoanalysis). A weak upper-air trough was also present over South Africa (Fig. 2a).

These synoptic settings and conditions (as indicated in Fig. 2) resulted in the western half of South Africa being hot and dry, while the eastern parts were cool and moist with low-level clouds present (Figs. 3-5). Figure 3 indicates that conditions that prevailed at 12:00 UTC, also prevailed throughout the afternoon (12:00 to 16:00 UTC; 14:00 to 18:00 local time; Fig. 4 and 5) with little fluctuation.

The 12:00 UTC surface dew point temperature analysis for 11 December 2017 conducted by operational forecasters at the SAWS indicated the presence of a dry line over the central Free State Province, which extended through the 


\section{Synoptic Analysis for 11 December 201712 UTC}

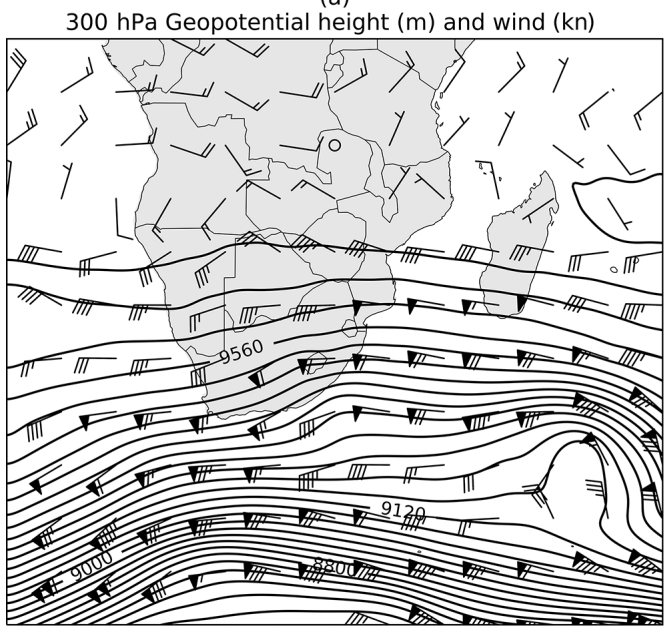

(c)

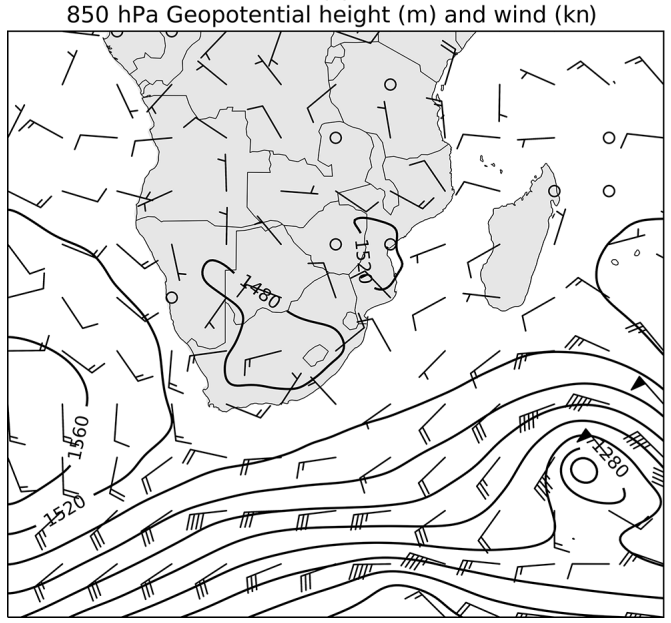

(b)

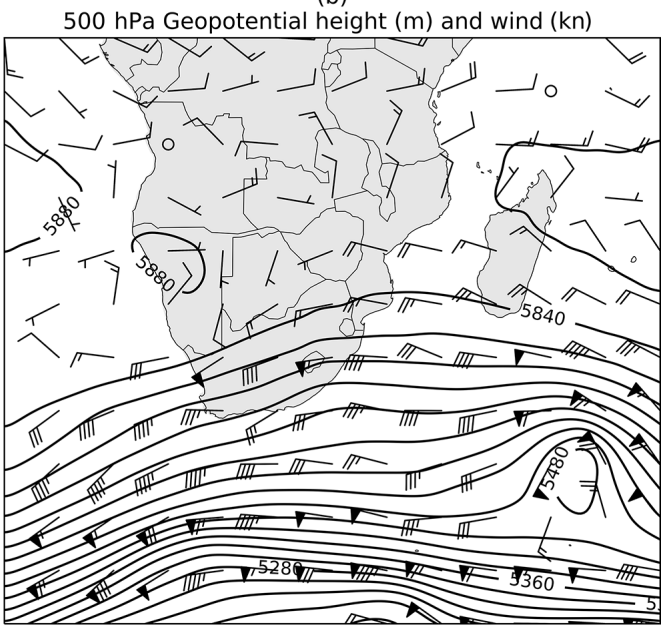

(d)

Mean sea level pressure (hPa) and $10 \mathrm{~m}$-wind $(\mathrm{kn})$

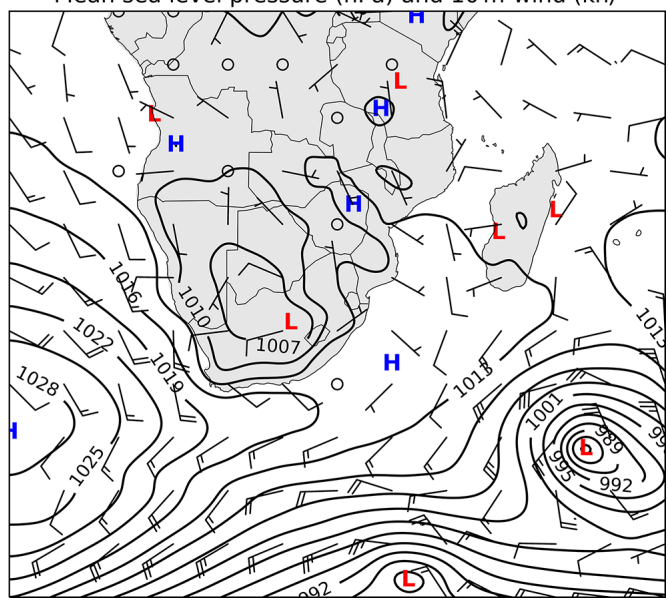

Figure 2. Synoptic chart analysis indicating mean sea level pressure (in $\mathrm{hPa}$ ) and 850, 500, and $300 \mathrm{hPa}$ Geopotential heights for $11 \mathrm{December}$ 2017 at 12:00 UTC over southern Africa and the surrounding oceans. Descriptions for each frame are contained in the body text.

south-western areas of the North West Province and southwestern parts of Botswana (Fig. 3). Figure 4 indicates that at 12:00 UTC, the reanalysis data compares well with that of the surface chart analysis. It also clearly indicates the dry line over the central Free State Province, which also extends through the south-western areas of the North West Province and south-western parts of Botswana. The dry line separated the hot dry air in the west from the warm moist air in the east and was moving eastwards after sunrise as differential heating allowed vertical mixing to entrain dry air from the west into the moist boundary layer to the east of the dry line. This dry line was responsible for initiating several severe convective storms in the Free State Province, from which one intensified into a supercell thunderstorm that lasted for $7 \mathrm{~h}$ and resulted in the observed VAM tornado.

\subsection{Mesoanalysis}

\subsubsection{Surface analysis}

Surface station data near the thunderstorm track were used for mesoanalysis. Data analysis from radar and four weather stations close to the location of the storm initiation (Potchefstroom, Soweto, Klerksdorp and Kroonstad) indicates that the storm of interest initiated after 13:00 UTC over a dry line. Figures 6 and 7 indicate that along the dry line there was a convergence of moist northerly winds and relatively dry westerly winds. Throughout the analysis period (from 10:00 to 22:00 UTC) Potchefstroom and Soweto recorded an advection of moist air from northerly winds, which respectively averaged 25 and $17 \mathrm{kn}$ between 13:00 and 14:00 UTC (Figs. 6 and 7a and b). During the same analysis period, sta- 


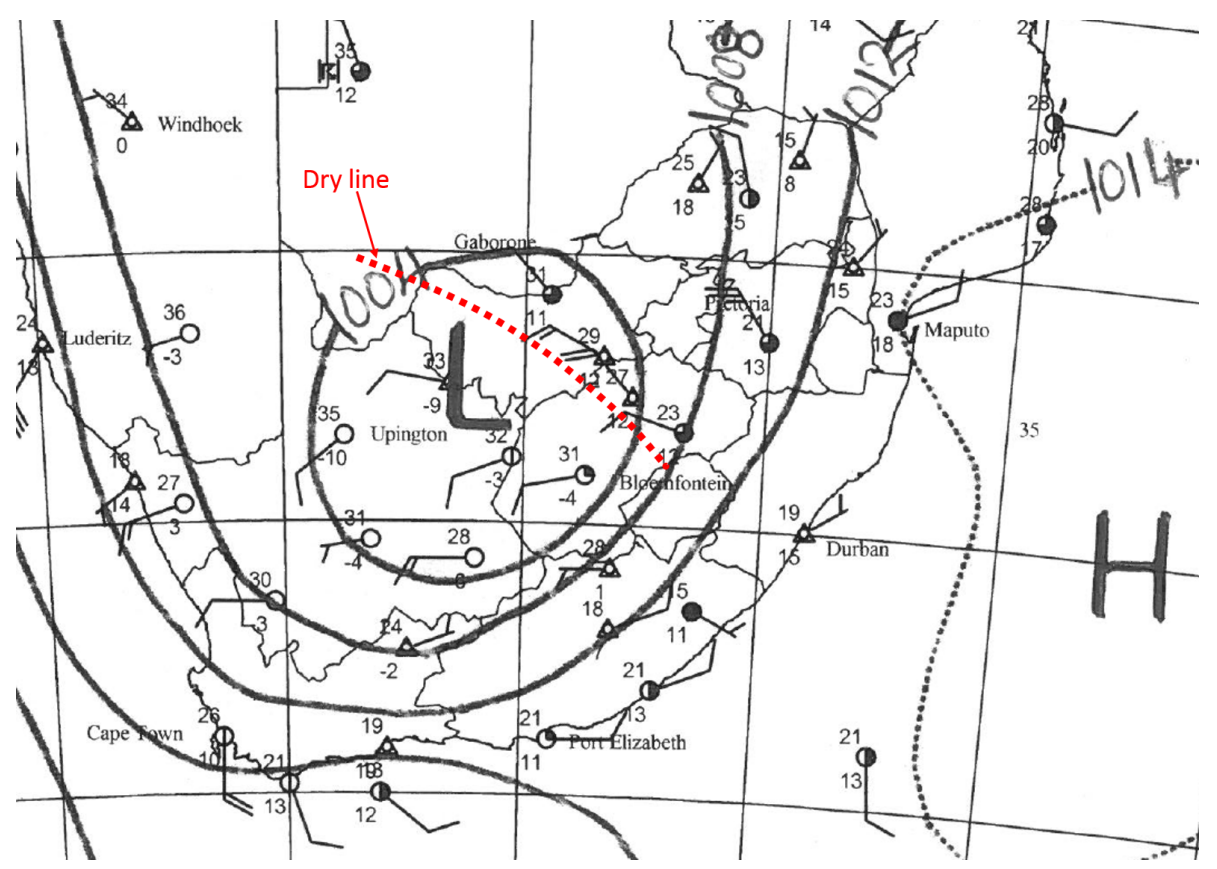

Figure 3. Surface chart analysis performed at the South African Weather Service for 12:00 UTC on 11 December 2017. The dry line is stretching from the Free State Province to the North West Province.

tions at Klerksdorp and Kroonstad reported an advection of warm moist air from north-westerly winds which eventually became hot and dry and changed to westerly after a passage of the dry line (Figs. 6 and 7c and d). The average hot and relatively dry winds in those stations between 13:00 and 14:00 UTC were $33 \mathrm{kn}$, with Kroonstad respectively recording 43 and $33 \mathrm{kn}$.

After initiation, the storm initially propagated eastwards and then suddenly changed direction to north-east towards the Vaal Dam as it matured into a supercell thunderstorm from a continual merger of several cells (see Fig. 1). As the supercell approached the Vaal Dam, it intensified further and was now associated with large hail and strong damaging winds, with the first sighting of a tornado near Deneysville (town in the north-western edge of the Vaal Dam). The now tornadic supercell then moved across the Vaal Dam and reached Vaal Marina (town in the north-eastern edge of the Vaal Dam), in the extreme south of the Gauteng Province. In Vaal Marina (and Mamello informal settlement), the supercell was still associated with large hail and strong damaging winds, and a tornado touchdown track of about $1.5 \mathrm{~km}$ $(1500 \mathrm{~m})$ was confirmed from a site visit (and by confirming this in situ data with radar and satellite data).

It might be significant to note that Frankfort station located a little over $50 \mathrm{~km}$ south-south-east of VAM (see Fig. 1) reported cool and moist southerly to south-easterly winds almost throughout the day (Fig. 7e) while stations north of VAM reported cool to warm and moist northerly to northwesterly winds. There is not enough surface data in the vicinity and south of VAM to know whether Frankfort wind speeds and directions generally represent mesoscale circulation at locations south and proximally closer to VAM since it is the only station available around that area. If it does represent mesoscale circulation south of VAM, then it is more likely that there was convergence of cool and moist air close to VAM before tornadogenesis occurred between Deneysville and Vaal Marina. It is important to note this because studies conducted by Seko et al. (2015) and Yokota et al. (2016) revealed that low-level water vapour and convergence near the storm are important factors for low-level mesocyclogenesis, which is a process important in supercell tornadogenesis.

\subsubsection{Soundings}

The 12:00 UTC Irene upper-air sounding (Fig. 8) captured north-north-easterly cool and moist surface winds of $10 \mathrm{kn}$ which back with height (turns anticlockwise with height, comparative to veering in the Northern Hemisphere) to westsouth-westerly at $500 \mathrm{hPa}$ to become $25 \mathrm{kn}$. The Bram Fischer International Airport (FABL) sounding indicates much greater mid-level winds of $45 \mathrm{kn}$ upstream. The FAIR and FABL upper-air soundings in Fig. 8 confirm winds captured by the synoptic analysis in Fig. 2 close to the soundings vicinity. This indicates significant directional shearing between the surface and the mid-troposphere, while the speed shearing was respectively weak in FAIR $(15 \mathrm{kn}$ at $500 \mathrm{hPa})$ to moderate $(40 \mathrm{kn}$ at $300 \mathrm{hPa})$. The FABL hodograph indicates unidirectional shearing, while that of FAIR is curved and has a common signature for classic supercell development. The 

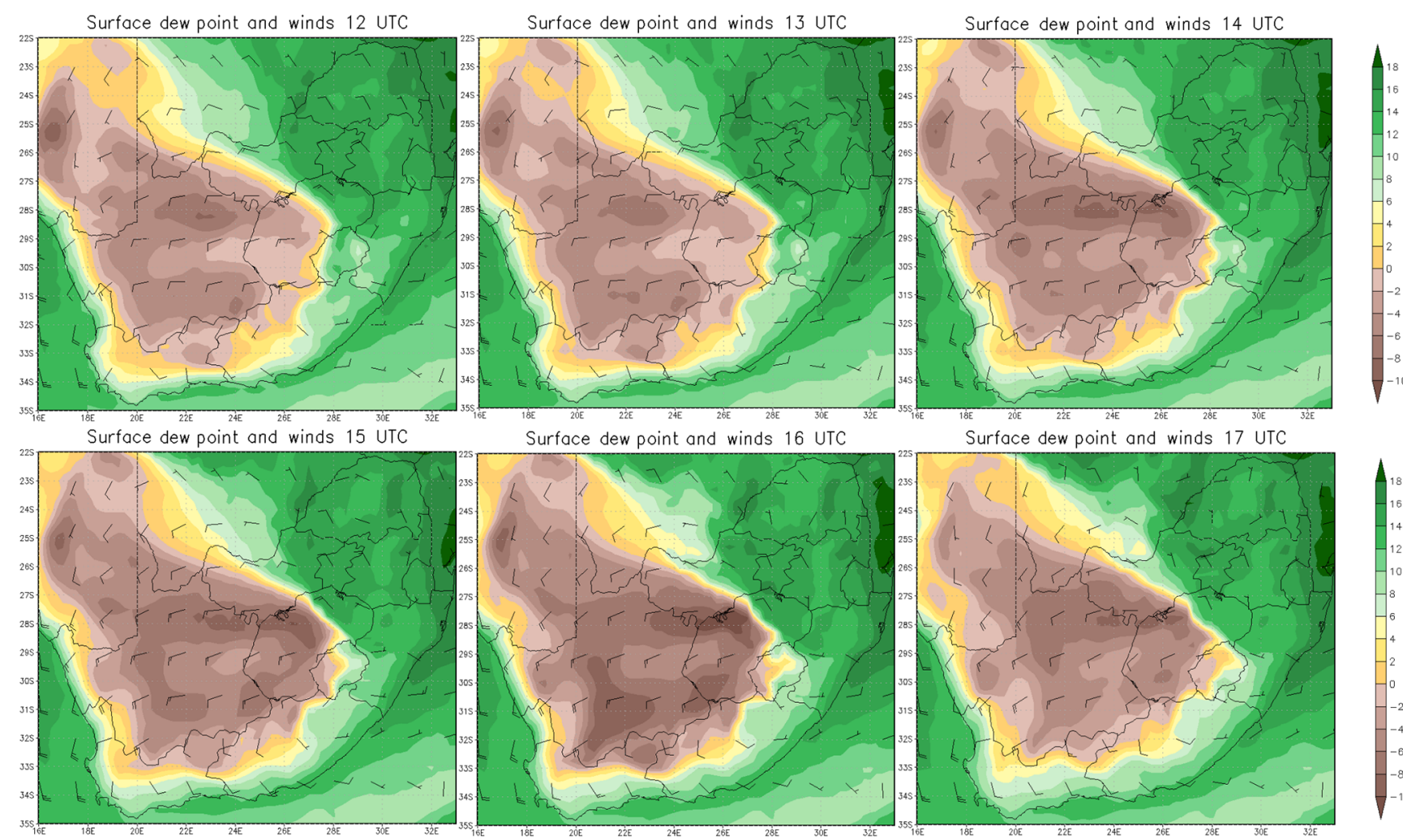

Surface dew point and winds 16 UTC

Surface dew point and winds 17 UTC
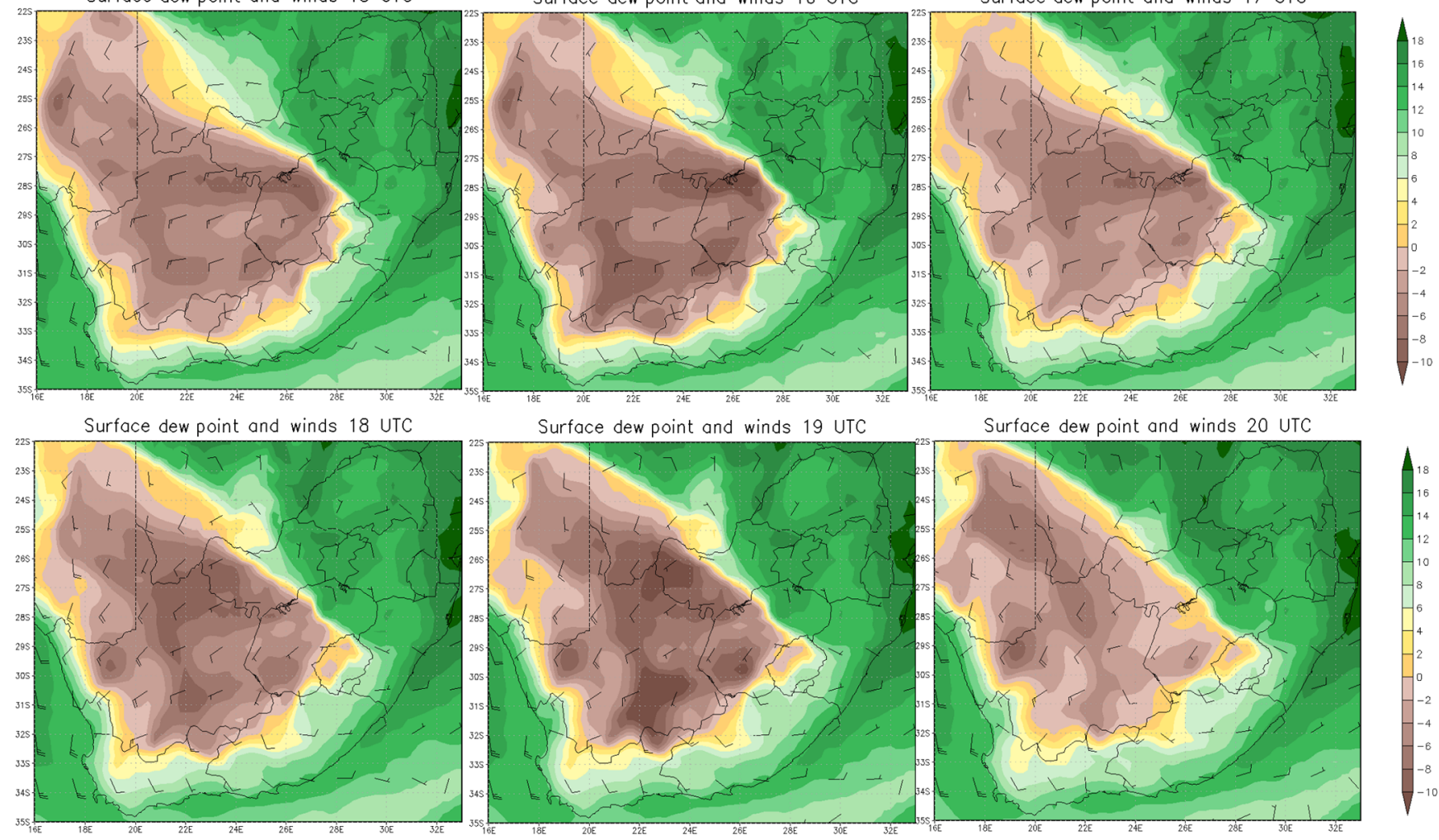

Surface dew point and winds 20 UTC

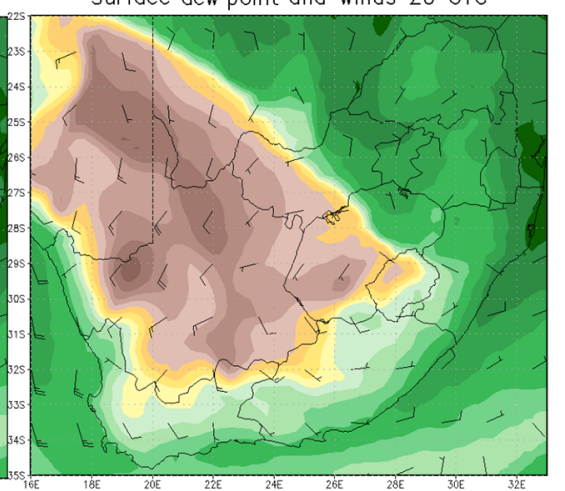

Figure 4. Surface dew point and wind analysis between 12:00 and 20:00 UTC. The dew point is in degrees Celsius ( $\left.{ }^{\circ} \mathrm{C}\right)$. The dry line can clearly be seen in the Free State Province and compares well with that identified by the surface chart analysis in Fig. 3.

FAIR sounding also indicates a $35 \mathrm{kn}$ lower mid-level jet and an upper-level west-north-westerly jet of $65 \mathrm{kn}$, which also confirm the synoptic analysis in Fig. 2. The lower levels were moist with an average relative humidity of $91 \%$ between the surface and $625 \mathrm{hPa}$, while the mid-levels were dry with relative humidity averaging $26 \%$ between 573 and $400 \mathrm{hPa}$.

\subsubsection{Lapse rate analysis}

ELR fields shown in Fig. 9 indicate that with availability of moisture and lift, deep convection was favourable in central and eastern South Africa. Between 10:00 and 14:00 UTC (12:00 and 14:00 local time), the mid-atmosphere between Irene and VAM had lapse rate values of between 6 and $7{ }^{\circ} \mathrm{Ckm}^{-1}$. These are comparable to lapse rates calculated from the Irene upper-air sounding (FAIR) released at 12:00 UTC, which was approximately $6.5^{\circ} \mathrm{C} \mathrm{km}^{-1}$, increasing our confidence that the ELRs from the ERA5 reanalysis are reliable. This indicates an atmosphere that was conditionally unstable between Irene and VAM. At the time and location of the storm initiation (15:24 local time (13:24 UTC), cf. Fig. 1), Fig. 9 indicates lapse rates of between 7 and $9{ }^{\circ} \mathrm{C} \mathrm{km}^{-1}$, implying an unstable atmosphere. As the storm was propagating north-eastward, ELRs along the storm track were increasing. Figure 9 further indicates that between 10:00 and 16:00 UTC (12:00 and 18:00 local time), lapse 

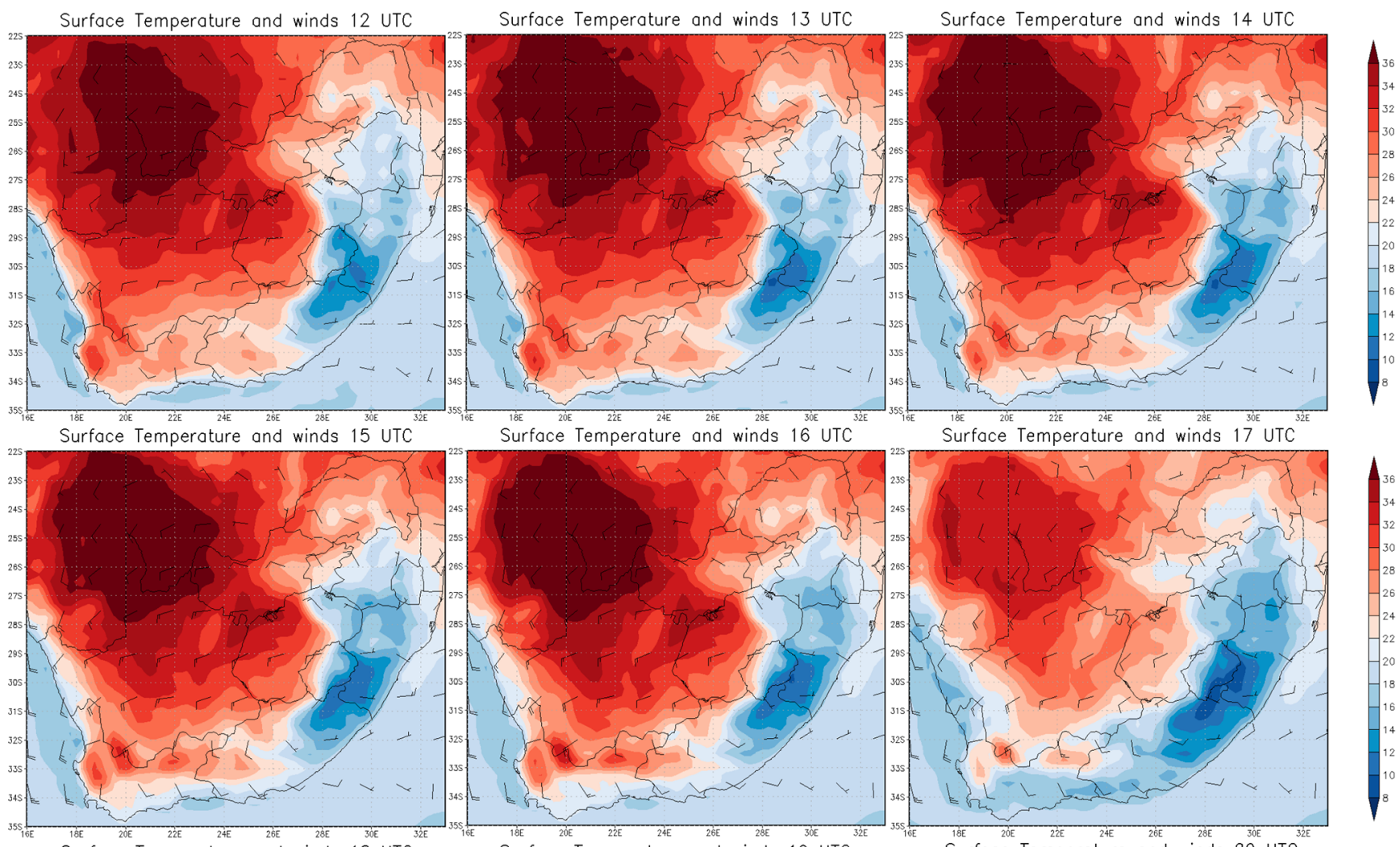

Surface Temperature and winds 16 UTC
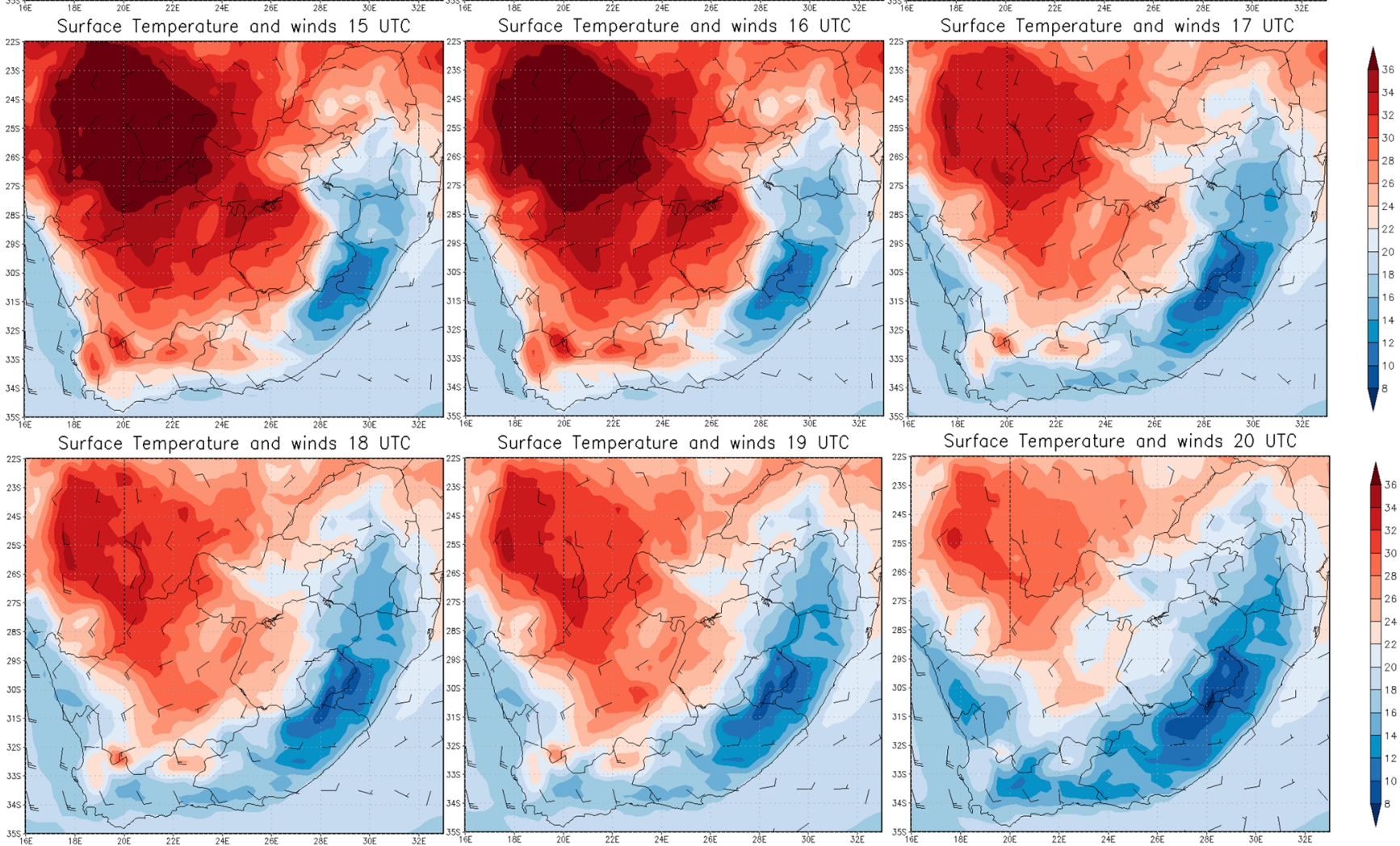

Figure 5. Surface temperature and wind analysis between 12:00 and 20:00 UTC. The temperature is in degrees Celsius $\left({ }^{\circ} \mathrm{C}\right)$. The analysis compares well with that of the surface chart analysis in Fig. 3.

rates between VAM and Machadodorp ranged between 6 and $7^{\circ} \mathrm{C} \mathrm{km}^{-1}$. Between 17:00 and 20:00 UTC (19:00 and 22:00 local time) the lapse rates in the same area ranged between 7 and $8{ }^{\circ} \mathrm{Ckm}^{-1}$. This analysis indicates an increasingly unstable atmosphere as the storm propagated north-eastward. The availability of low-level moisture, conditionally unstable atmosphere, and vertical wind shearing made it possible for the storm to initiate, intensify to supercell, and then be maintained for $7 \mathrm{~h}$.

Therefore, the availability of low-level moisture, steep mid-level lapse rates, and vertical wind shearing provided favourable conditions for the possibility of dynamically and thermodynamically induced organised severe thunder- storms (including supercell type) developing in the vicinity. This analysis indicates that three ingredients important for strengthening and maintaining typical supercell thunderstorms were present and can be summarised for this case as follows: significant surface to mid-level vertical shear, an abundance of low-level warm moisture influx from the tropics and Mozambique Channel, and the unstable mid-levels as a result of steep mid-level lapse rates. Prevailing synoptic environmental conditions further show that these ingredients also prevailed in the eastern parts of the country, over the Highveld region (see Fig. 1), and therefore along the vicinity of the storm track, which indicates that they likely played a 


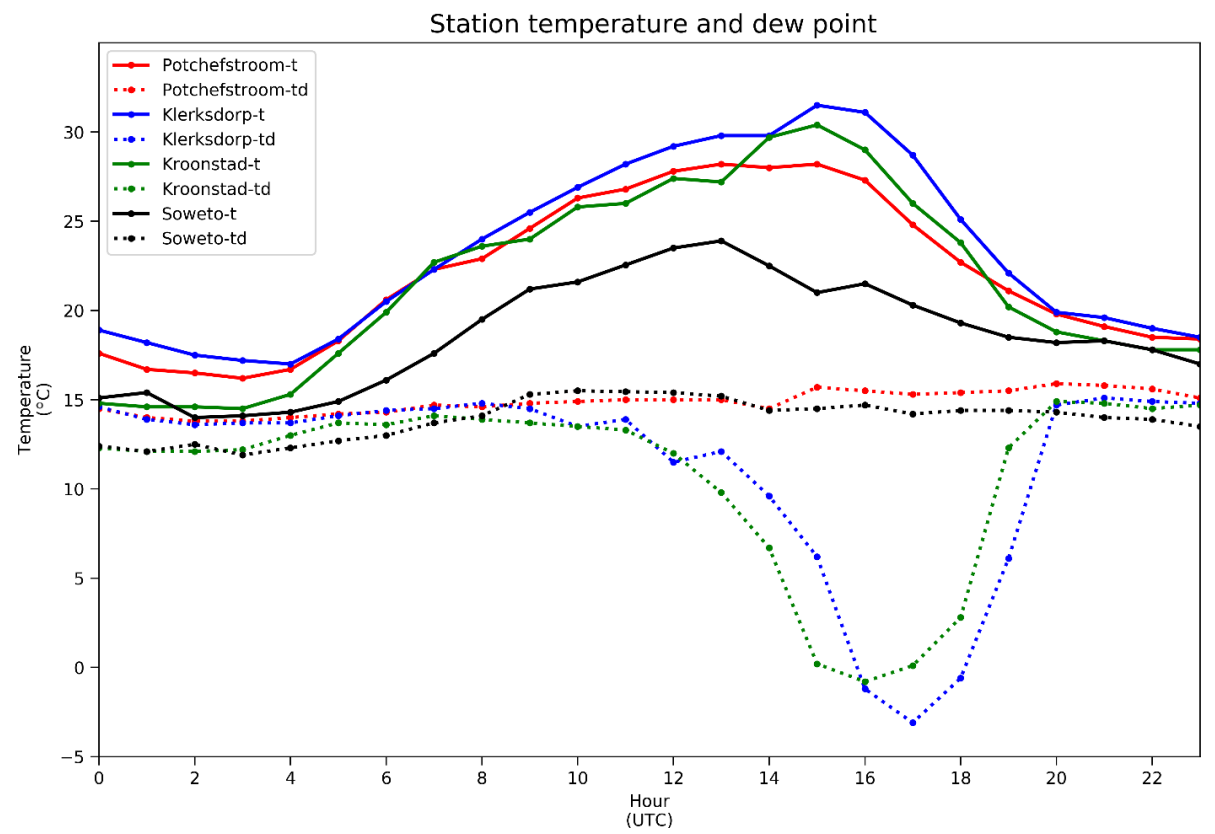

Figure 6. The graph is indicating changes in temperature and dew point temperature as reported by four weather stations located proximally closer to the location of the storm initiation between 00:00 and 23:00 UTC on 11 December 2017.
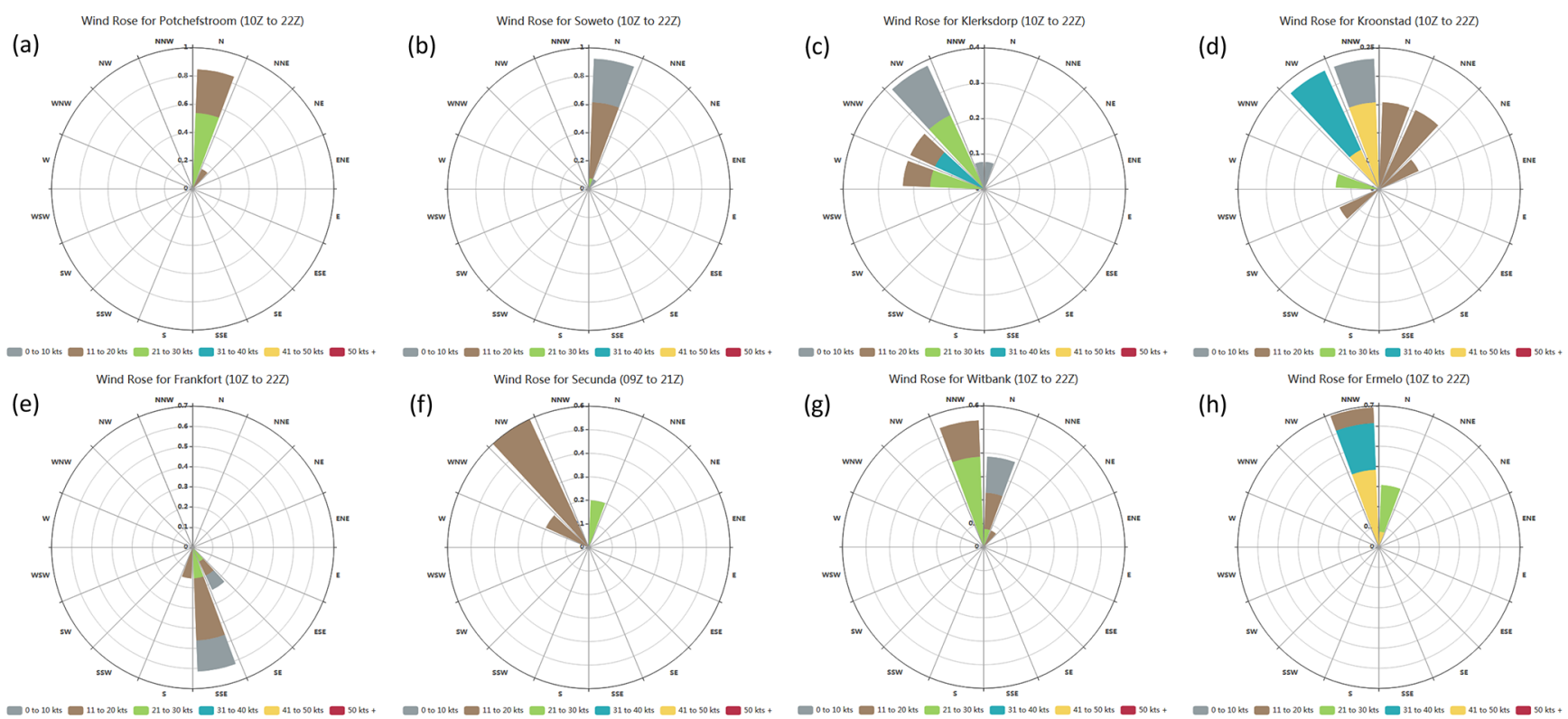

Figure 7. Wind rose diagrams of eight weather stations proximally closer to the storm track (as depicted in Fig. 1) between 10:00 and 22:00 UTC on 11 December 2017.

role in ensuring that the supercell storm is strengthened and maintained throughout its lifetime.

\subsubsection{Radar data}

A hook echo can clearly be seen from the low levels of the storm between 15:16 and 15:34 UTC as observed by the first sweep of the Irene radar (at an elevation angle of $0.5^{\circ}$ )
(Fig. 10). Figure 10a indicates a hook echo west of the Vaal Dam at 15:16 UTC which was associated with local strong cyclonically rotating winds as indicated by the radial velocity inbound-outbound maxima in Fig. 10b (this could explain the tornado observed near Deneysville). A hook echo was also observed 12 min later at 15:28 UTC over Mamello, an informal settlement located in the eastern outskirts of Vaal Marina (Fig. 10e). Figure 10f indicates that this hook echo 
Irene (FAIR) Sounding and Hodograph. Valid: 12 UTC 11 Dec 2017

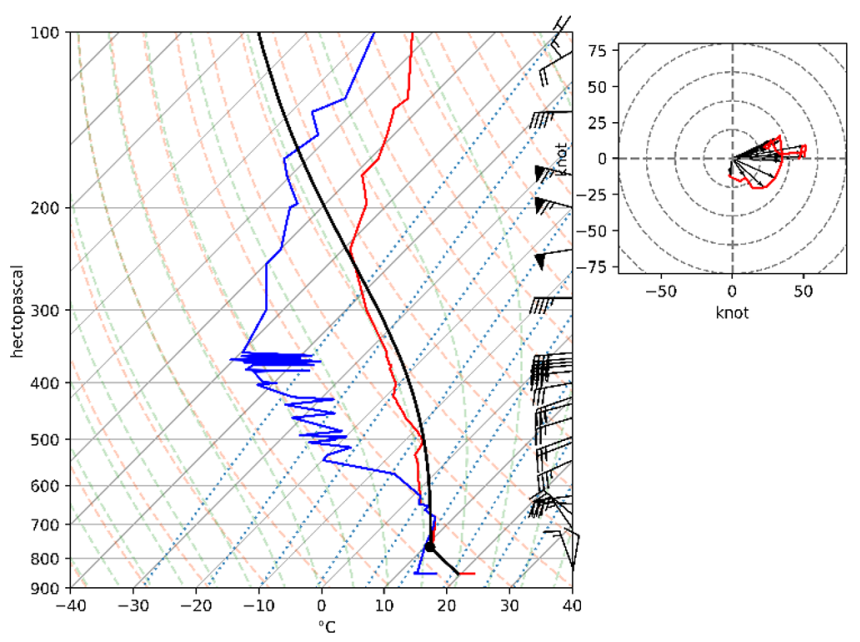

Bloemfontein (FABL) Sounding and Hodograph. Valid: 12 UTC 11 Dec 2017

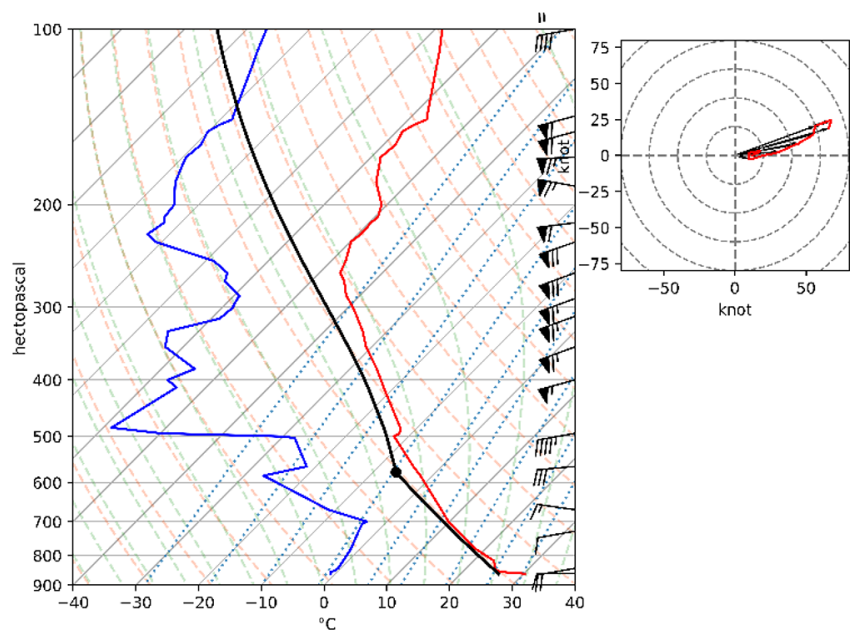

Figure 8. Irene (FAIR) upper-air sounding at 12:00 UTC on 11 December 2017. This is used to proximate atmospheric conditions over VAM. The Bram Fischer International Airport (FABL) upper-air sounding at 12:00 UTC is also included and indicates upstream mid-level winds of about $45 \mathrm{kn}$. Hodographs are included for each sounding, indicating wind shear between the surface and $10 \mathrm{~km}$ above ground level.

over Mamello was also associated with local strong circulating winds. This analysis indicates that it is most likely that the tornado that was reported to have devastated VAM touched down multiple times between 15:15 and 15:30 UTC (17:15 and 17:30 local time) but could also have been on the ground during this entire period or for a period longer than the mesocyclone that was captured by the radar.

After passing through the VAM area, the supercell continued in the north-easterly direction, weakening and strengthening throughout before dissipating just before reaching Machadodorp in Mpumalanga Province. Near the storm track throughout (except for Frankfort), surface winds were variable between northerly and north-westerly (Fig. 7). The supercell dissipated on approach to Machadodorp, where winds were variable between north-easterly to easterly between 19:00 and 20:00 UTC (21:00 and 22:00 local time) and averaged $8 \mathrm{kn}$.

\subsection{Unified Model analysis}

The $24 \mathrm{~h}$ rainfall total is shown in Fig. 11 for both SA1.5 and SA4.4, as well as the ERA5 reanalyses and IMERG, which represents observations. Both the ERA5 and IMERG captured rainfall in the area where the storm passed; however, there are differences in the two datasets. For example, IMERG indicates a large amount of rainfall in the north-east border of the plot. The ERA5 shows a large amount of rainfall only in the south-east of the domain shown. The SA4.4 simulated a large amount of rainfall in different parts of the domain, while the SA1.5 only simulated a large amount of rainfall in the south-east border of the domain. We also investigated the timing of rainfall in the SA4.4 and found that the model predicted a precipitating storm propagating north of
VAM between 15:00 and 16:00 UTC. The timing of this precipitating storm as predicted by SA4.4 was correct; however, the location was slightly north of the actual observation (cf. Fig. 10). This is a common issue with convection-permitting models which prompted the scientific community to develop new metrics to verify these types of models to avoid penalising them twice for misplacing rainfall (e.g. Davis et al., 2009; Gilleland et al., 2009). On the other hand, SA1.5 failed to predict any precipitation close to VAM between 15:00 and 16:00 UTC or anytime during the analysis period (between 12:00 and 24:00 UTC) (see Fig. 11).

An analysis of the $10 \mathrm{~m}$ wind directions in SA4.4 and SA1.5 generally agrees with observed surface northerly to north-westerly wind directions close to VAM; however, the wind speeds are underestimated in both models (Fig. 12). Figure $12 \mathrm{a}$ and $\mathrm{b}$ show that SA1.5 and SA4.4 predicted almost similar wind speeds at 15:00 UTC, which are underestimated compared to observations (Fig. 12d). The simulated wind speeds by the UM are more similar to the ERA5 (Fig. 12c), and the similarities are larger with the SA4.4. The ERA5 winds are also lower than those observed using SAWS ground stations. A sample of three stations along the storm track taken proximally closer to the location of initiation, propagation, and dissipation stages of the storm (Klerksdorp, Witbank (also known as Emalahleni) and Machadodorp) indicates that SA4.4 and SA1.5 especially underestimated the wind speeds during the initiation stage of the storm (Fig. 13). The ERA5 winds are stronger than both UM configurations, despite the ERA5's lower resolution compared to these configurations.

The SA4.4 generally indicates westerly and southwesterly $500 \mathrm{hPa}$ winds at 15:00 UTC over VAM (Fig. 14). Considering surface winds, the SA4.4 indicates the pres- 


\section{Mid-level Lapse Rates $\left({ }^{\circ} \mathrm{C} / \mathrm{km}\right)$ on 11 December 2017}
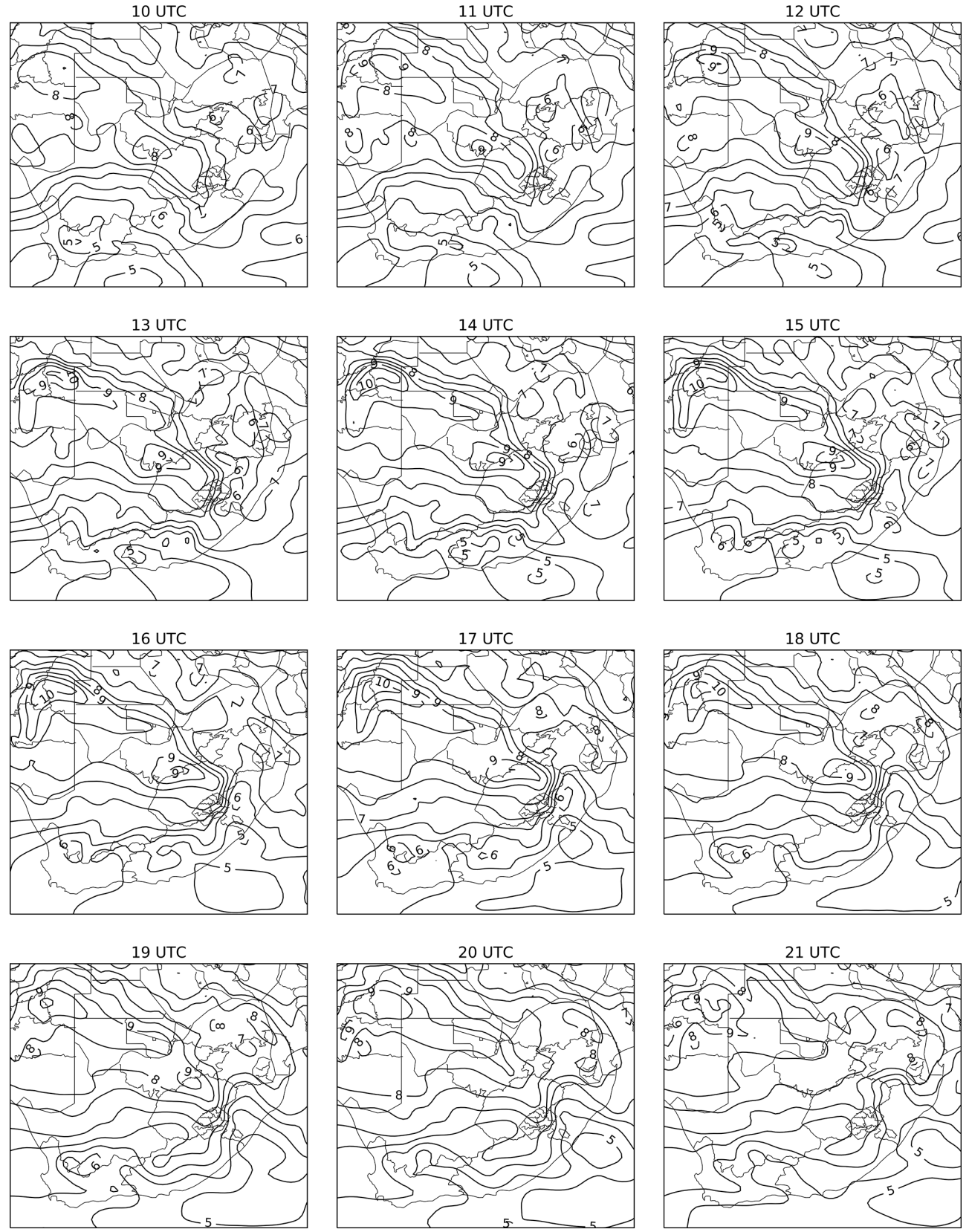

Figure 9. Environmental lapse rates (in ${ }^{\circ} \mathrm{C} \mathrm{km}^{-1}$ ) fields calculated between 700 and $500 \mathrm{hPa}$ (mid-levels) from ERA5 reanalysis. The fields have an interval of $0.5^{\circ} \mathrm{Ckm}^{-1}$.

ence of vertical shear between the surface and the mid-levels; however, the speed shearing is possibly underestimated especially during the initiation phase of the storm. The SA4.4 predicted a south-westerly propagation of $500 \mathrm{hPa}$ vertical vorticity north of VAM between 15:00 and 16:00 UTC (Fig. 14). The maximum negative vorticity at $500 \mathrm{hPa}$ reached by the VAM storm, as predicted by SA4.4, ranged between $-0.5 \times$ $10^{-2}$ and $-0.75 \times 10^{-2} \mathrm{~s}^{-1}$ from 16:00 and 17:00 UTC. This vertical vorticity was 1 order of magnitude smaller than a dynamical definition of a mesocyclone, which is an indicator that SA4.4 did not capture the mesocyclone of the VAM storm and therefore underestimated its severity. However, contrary to supercell storms in the midlatitudes, most storms developing in the subtropics (which is where South Africa is located) do so without strong vertical shear and are rather associated with weak or moderate vertical wind shear (Sansom, 1966; Hand and Cappelluti, 2011). It may therefore be argued that relatively lower amounts of vertical wind shear 


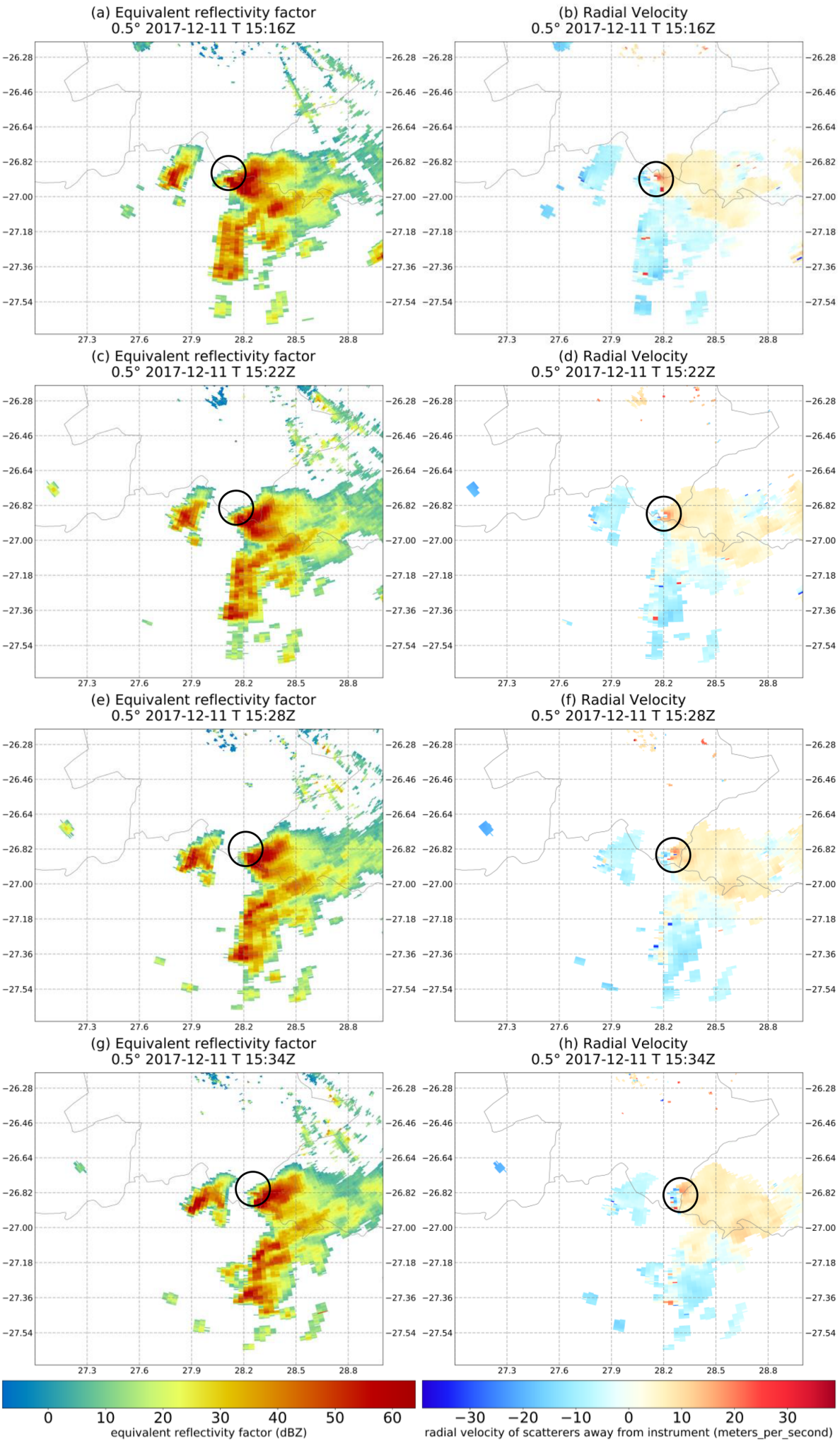

Figure 10. Irene radar equivalent reflectivity factor $(\mathrm{dBZ})$ and radial velocity of scatterers $\left(\mathrm{m} \mathrm{s}^{-1}\right)$ of the supercell thunderstorm as plotted using the Python ARM Radar Toolkit (Py-ART) (Helmus and Collis, 2016). Panel (a), (c), (e), and (g) indicate low-level reflectivity as captured by the first radar sweep at an elevation angle of $0.5^{\circ}$ for every $6 \mathrm{~min}$, between 15:16 and 15:34 UTC. Panel (b), (d), (f), and (h) radar scans have similar properties to the panel (a), (c), (e), and (g) radar scans but for the radial velocity of scatterers. 

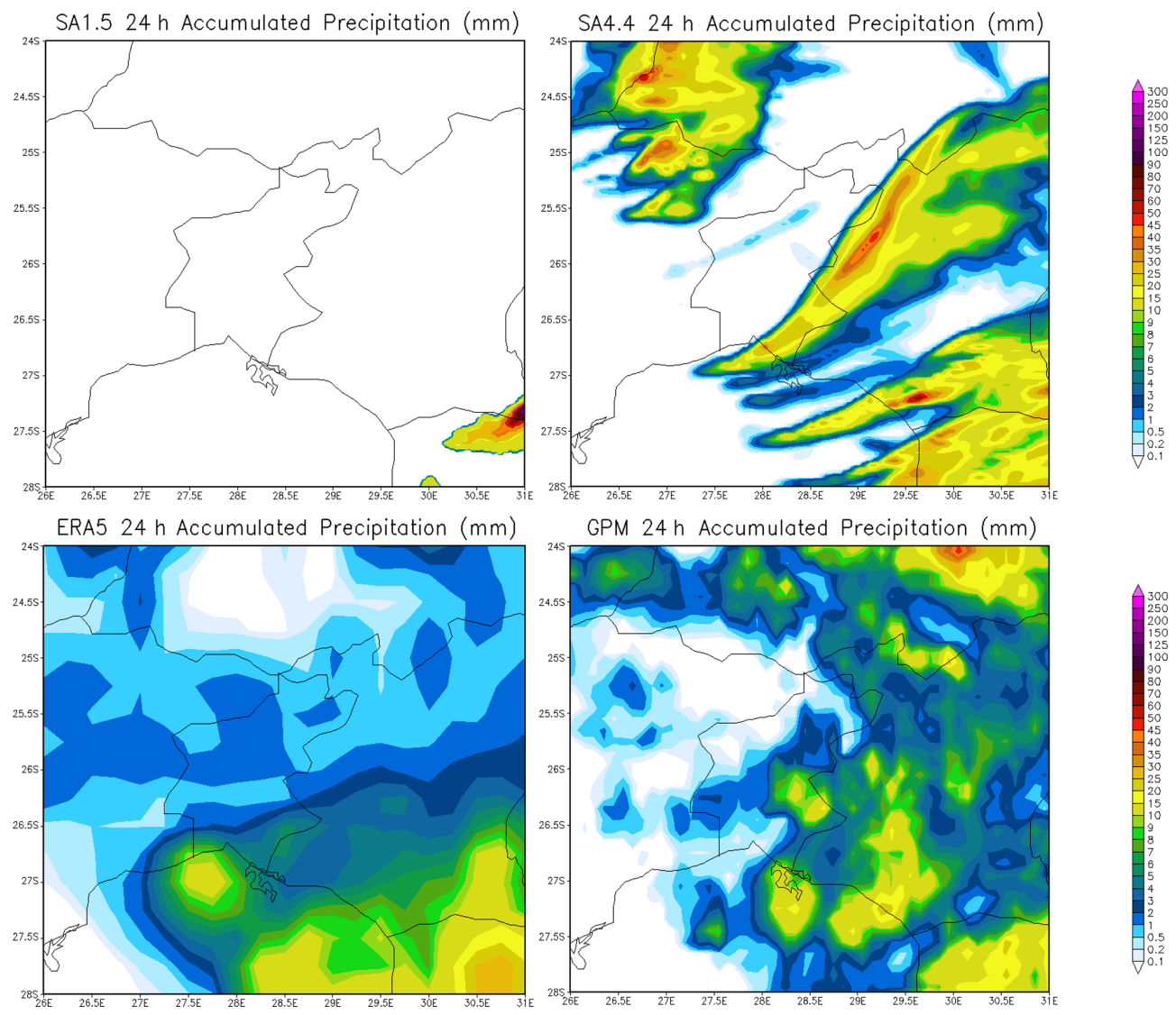

Figure 11. Total precipitation for 11 December 2017, in the area of interest (in mm) as predicted by SA1.5 and SA4.4, and also from ERA5 and GPM.

in the subtropics, and in our case study, correlate with relatively lower relative vertical vorticity and therefore relatively weaker mesocyclone according to classical definitions as stated by Glickman (2000).

A relationship between MFC and vertical vorticity was also determined. It was found that SA4.4 predicted vorticity maxima at $500 \mathrm{hPa}$, which is associated with MFC maxima at low levels. MFC initiates first at the low level followed by vorticity genesis at $500 \mathrm{hPa}$. This implies that the development of MFC in the low levels could be a precursor of vertical vorticity initiation in the mid-levels. Since there is a positive relationship between low-level MFC and mid-level vorticity, it follows that the stronger the low-level MFC, the stronger the mid-level vorticity would be. This finding is in agreement with a study by Banacos and Schultz (2005).

Further examination of the VAM storm during its $500 \mathrm{hPa}$ vorticity maxima as predicted by SA4.4 (which occurred between 16:00 and 17:00 UTC) reveals that low-level convergence occurred in the equatorward side of the storm and divergence in the polarward side of the storm. Figure 15a indicates that low-level convergence was associated with relatively higher values of specific humidity. This implies that there is an inflow of low-level moist air which converges in the equatorward side of the storm and then gets uplifted as updraughts. Figure 15a also indicates that low-level divergence is associated with relatively lower values of specific humidity, which implies that there is low-level diverging dry air in the polarward side of the storm. Figure $15 \mathrm{~b}$ shows that the low-level diverging dry air depicted in Fig. 15a particularly originates from the mid-levels.

The analysis also indicates a coupling of $800 \mathrm{hPa}$ convergence (divergence) fields with $500 \mathrm{hPa}$ (divergence) convergence fields, which is an indicator that the low-level converging moist air in the equatorward side of the storm gets uplifted with updraughts to the dry mid-levels and then later gets advected to the low levels with the downdraughts in the polarward side of the storm (Fig. 15a and b).

Figure $15 \mathrm{c}$ depicts $10 \mathrm{~m}$ winds and convergence (divergence) analysis. It should be noted that this analysis indicates that near-surface convergence (divergence) field patterns are similar to those at $800 \mathrm{hPa}$ shown in Fig. 15a, which are together coupled with $500 \mathrm{hPa}$ divergence (convergence) fields shown in Fig. 15b. Figure 15c indicates that there are two areas of updraught origin near the surface (ahead of the storm and at the rear flank of the storm), which are both located in the equatorward side of the storm, as also confirmed by the 
(a)

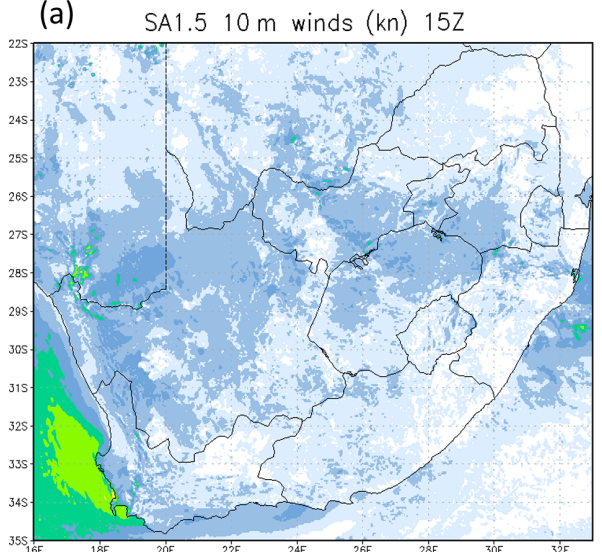

(c) ERA $10 \mathrm{~m}$ winds $(\mathrm{kn}) 15 \mathrm{Z}$

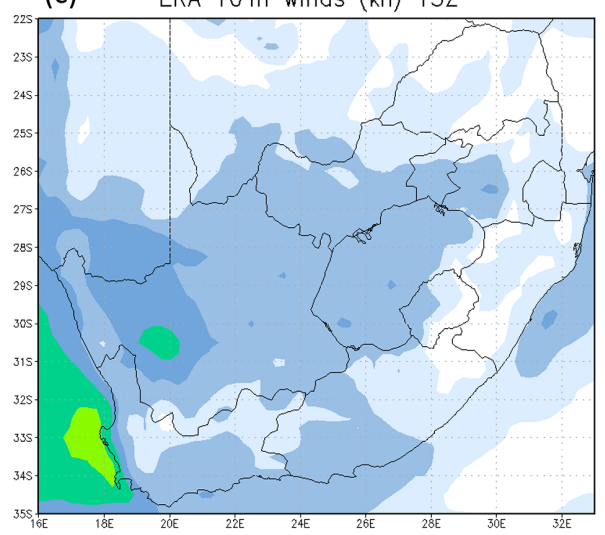

(b)

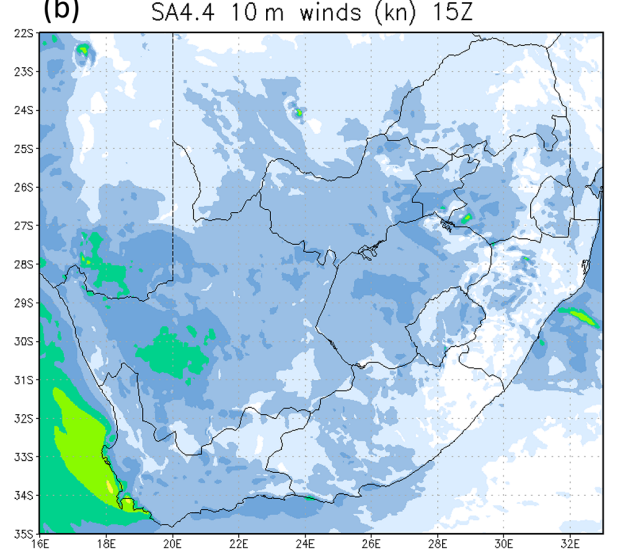

(d) Observed $10 \mathrm{~m}$ winds $(\mathrm{kn}) 15 \mathrm{Z}$

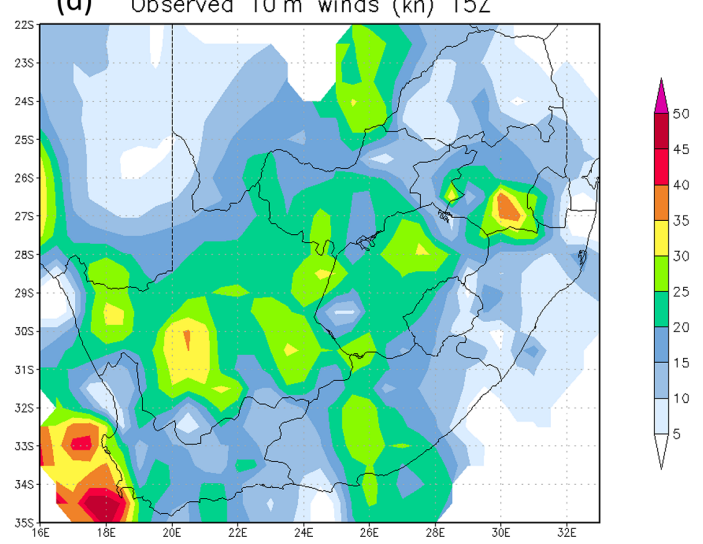

Figure 12. A comparison of observed surface wind speed from weather stations across South Africa at 15:00 UTC (d) with 10 m predicted winds by (a) SA1.5 and (b) SA4.4. Panel (c) indicates ERA5 winds. All the wind magnitudes are given in knots at an interval of $5 \mathrm{kn}$.

mid-level convergence and vorticity analysis (Fig. 15d). Figure $15 \mathrm{c}$ also indicates areas of forward-flank and rear-flank downdraughts, which are in the polarward side of the storm, as also confirmed by the mid-level convergence and vorticity analysis (Fig. 15d).

Figure 15 can be summarised as follows. There is a convergence of moist and relatively stronger surface and low-level winds ahead of the storm which are uplifted as updraughts to the mid-levels. Some of these updraughts diverge as they reach the mid-levels and are later advected to the lower levels and surface as relatively dry downdraughts, which then also diverge ahead of the downdraught area (toward the northeast as part of a front-flank gust front) and toward the rear flank of the storm (toward the west as part of a rear-flank gust front) on reaching the surface. The north-eastward diverging winds then contribute to uplifting the inflowing moist air ahead of the storm. On the other hand, the westward diverging winds converge with north-westerly inflowing moist air in the rear flank of the storm, initiating a second area of updraughts in the rear flank of the storm. These rear-flank updraughts also diverge in the mid-levels and contribute to the forward-flank downdraughts. The diverging mid-level winds from the rear-flank updraughts also converge with mid-level dry air which is being entrained from behind the storm and are later advected to the surface as the rear-flank downdraughts. Figure 15 further indicates that surface and lowlevel convergence is associated with the storm's cyclonic updraughts, while divergence is associated with anticyclonic downdraughts.

It is interesting to note that this analysis indicates that SA4.4 predicted thunderstorm dynamics consistent with those of a classic supercell. Therefore, from a dynamical perspective, SA4.4 was able to predict the VAM supercell, even though its strength was underestimated and location was incorrect possibly due to a lack of data assimilation.

\section{Summary and conclusion}

In this study an analysis of the tornadic supercell that tracked through the northern parts of the Highveld in South Africa on 11 December 2017 was performed. It was found that this supercell initialised in the Free State Province as part of a cluster of multicellular thunderstorms over a dry line and propagated in a north-easterly direction while strengthening and weakening throughout its lifetime, until it dissipated $7 \mathrm{~h}$ later 


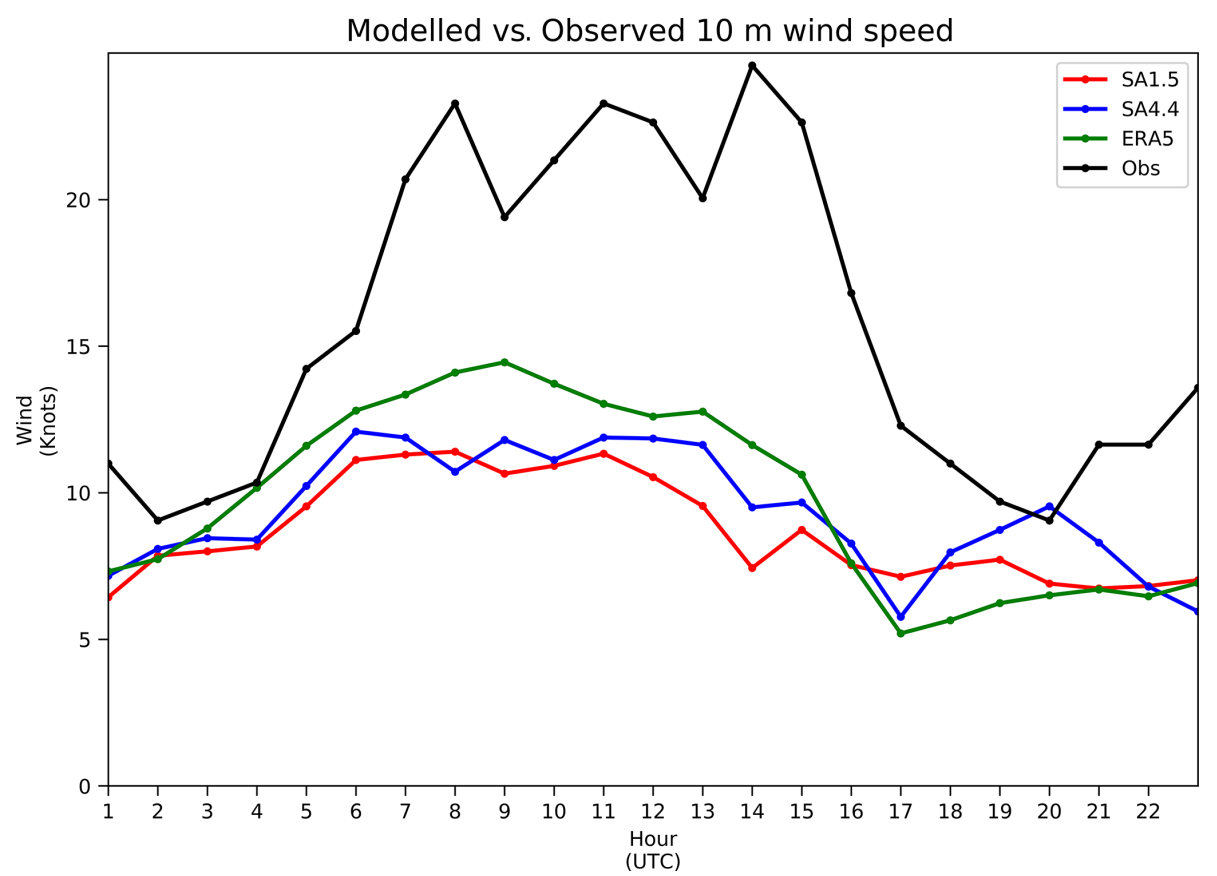

Figure 13. A comparison of average wind speeds from three stations along the storm track (Obs) compared to SA1.5, SA4.4, and ERA5 data for those stations between 01:00 and 23:00 UTC. All the wind magnitudes are given in knots at an interval of 5kn.

on approach to Machadodorp in the Mpumalanga Province. It was also found that three ingredients were likely important in strengthening and maintaining this supercell: significant surface to mid-level vertical shear, an abundance of lowlevel warm moisture influx from the tropics and Mozambique Channel, and the steep mid-level lapse rates.

On approach to the extreme south of the Gauteng Province, the already severe supercell encountered even more low-level moisture in the area which resulted in a tornado being initiated south of Deneysville town at approximately 17:15 local time. The supercell tracked through the Vaal Dam and continued through the town of Vaal Marina and the Mamello informal settlement at around 17:30 local time.

NWP models operationally run at the SAWS were also analysed and evaluated to see how they performed in predicting this tornadic supercell. It was found that the $4.4 \mathrm{~km}$ grid spacing model (SA4.4) performed better than the $1.5 \mathrm{~km}$ grid spacing model (SA1.5) in predicting this supercell. This is in spite of the horizontal resolution of SA1.5 being higher than that of SA4.4 and, therefore, expected to be able to represent small-scale atmospheric processes better. The poor performance of SA1.5 might have emanated from a significant underestimation in low-level warm moisture advection and convergence (which act as dynamic lifting mechanisms). Alternatively, it could be a case of missed convection initiation. Keat et al. (2019) have found that most rainfall, as simulated by SA1.5, is produced by large storms of at least $50 \mathrm{~km}$ in diameter. In our study, radar indicates that the storm being analysed had a diameter of between 20 and $30 \mathrm{~km}$, which may provide an explanation of why SA1.5 does not capture any storm, and therefore may be a case of missed convection initiation.

SA4.4 was able to capture the supercell being analysed. However, the severity of this supercell was underestimated, possibly due to an underestimation in the mid-level vorticity which was found to be 1 order of magnitude smaller than that of a typical mesocyclone. This underestimation in midlevel vorticity might be a result of poor model resolution of surface to mid-level vertical wind shear and low-level horizontal mass and moisture flux convergence, due to the model grid spacing. The poor model resolution is, therefore, a possible explanation of why SA4.4 might have underestimated the mesocyclone. SA4.4 also predicted a correct timing of the supercell; however. the location was incorrect, which is a common issue found in convection-permitting models. This result is consistent with those from studies by Stein et al. (2019), which found that while the correct cover of rainfall may be predicted by SA4.4, it may be predicted in the wrong location.

From these results, it is recommended that research into the possibility and benefits of implementing dynamic and thermodynamic objective analysis schemes, which are derived from both NWP model data output and near-real-time surface and upper-air observations, be conducted for a veryshort-range objective prediction of severe thunderstorm (including supercells) initiation over the central and eastern parts of South Africa. 

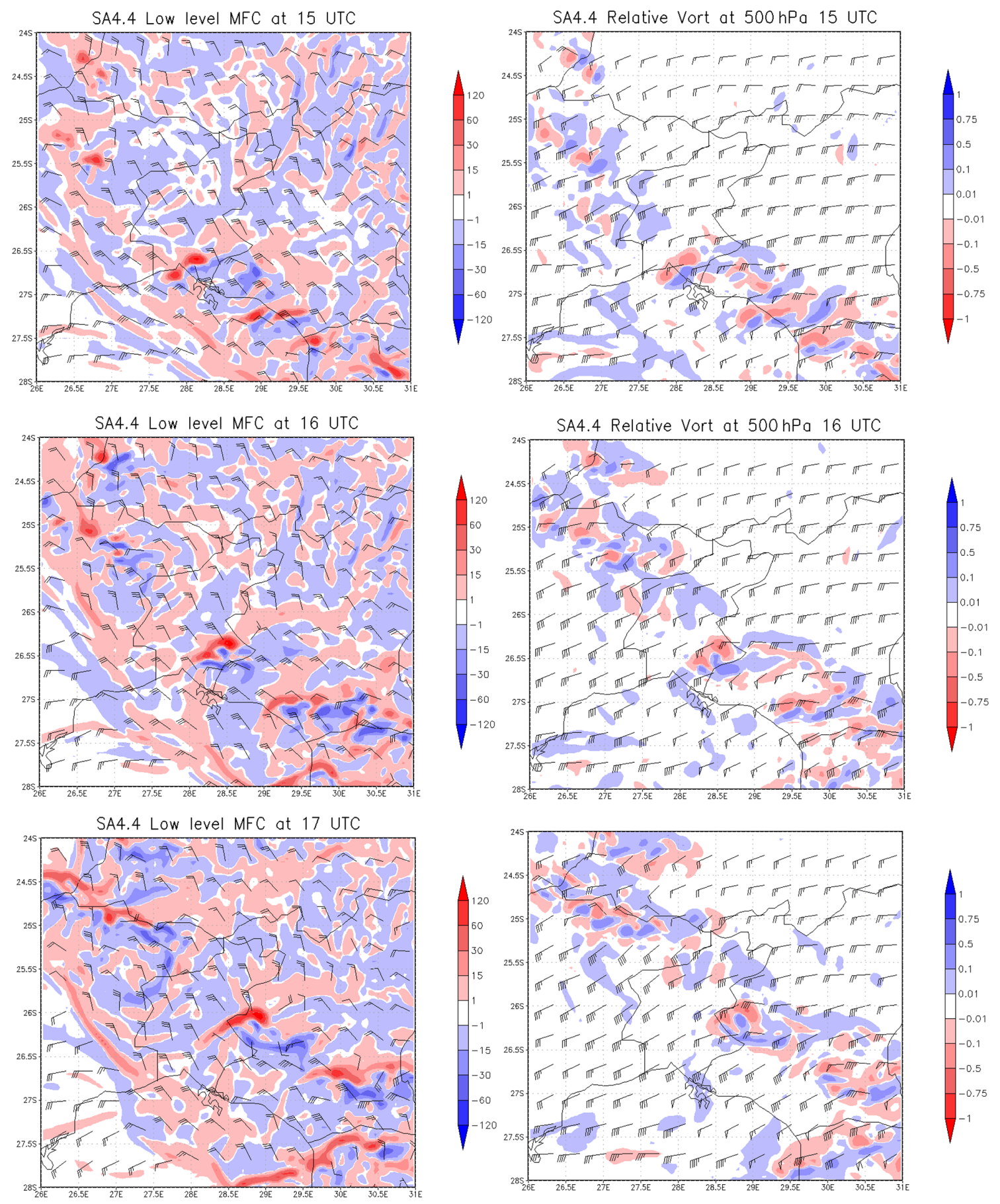

Figure 14. Low-level MFC and $500 \mathrm{hPa}$ relative vorticity and wind barbs as depicted by SA4.4. The shades in the relative vorticity figures represent negative (red) and positive (blue) relative vorticity in $10^{-2} \mathrm{~s}^{-1}$. MFC is in $10^{-6} \mathrm{~g} \mathrm{~kg}^{-1} \mathrm{~s}^{-1}$, with positive values (red shades) representing areas of convergence of moisture and negative values (blue) representing areas of divergence of moisture. 
(a) SA4.4 $800 \mathrm{hPa}$ convergence and specific humidity at $16 \mathrm{Z}$ Run 11:00

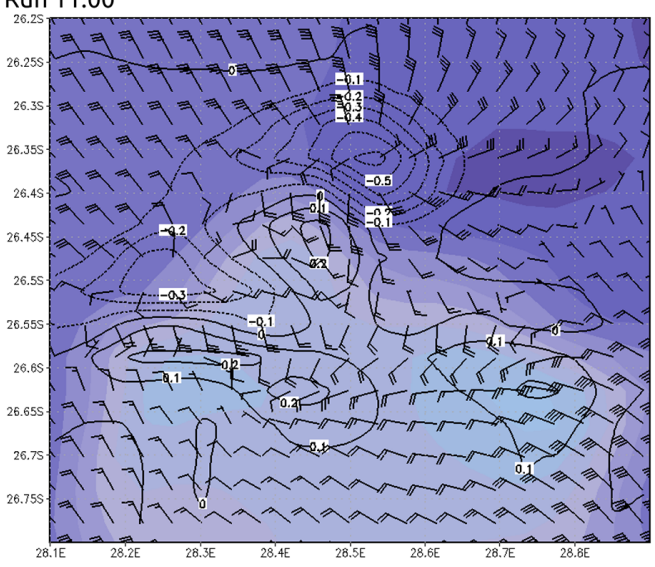

(c) SA4.4 $10 \mathrm{~m}$ convergence and winds at 16Z Run 11:00

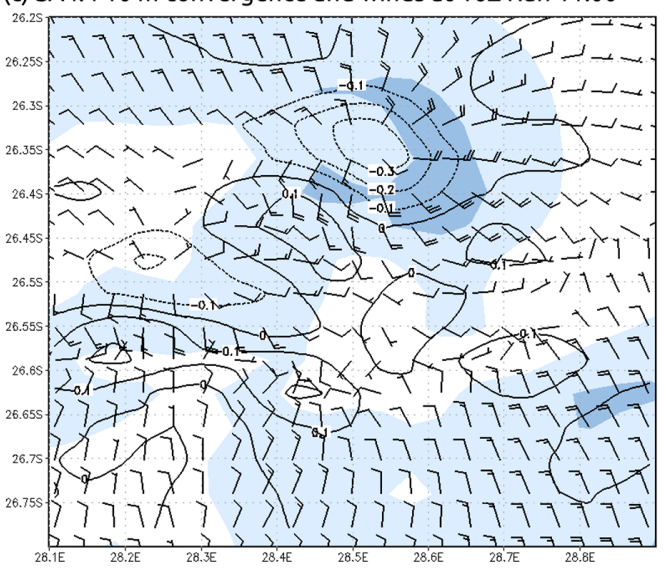

(b) SA4.4 $500 \mathrm{hPa}$ convergence and specific humidity at $16 \mathrm{Z}$ Run 11:00

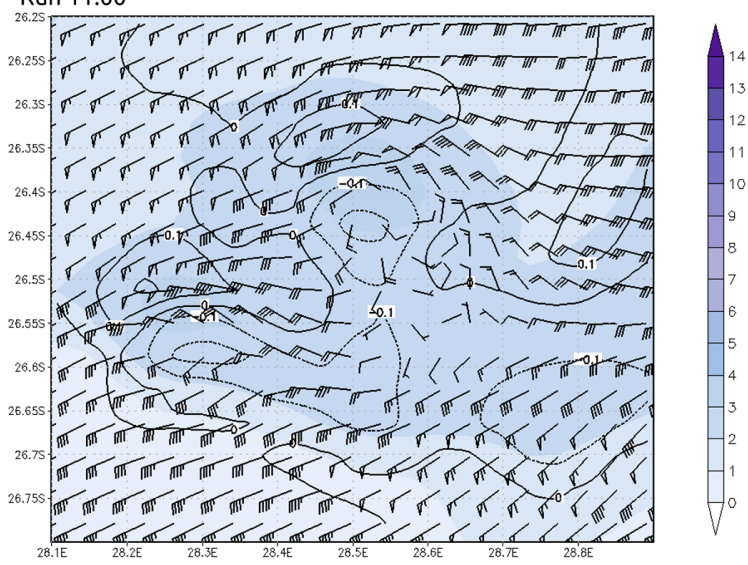

(d) SA4.4 $500 \mathrm{hPa}$ convergence and vorticity at $16 \mathrm{Z}$ Run 11:00

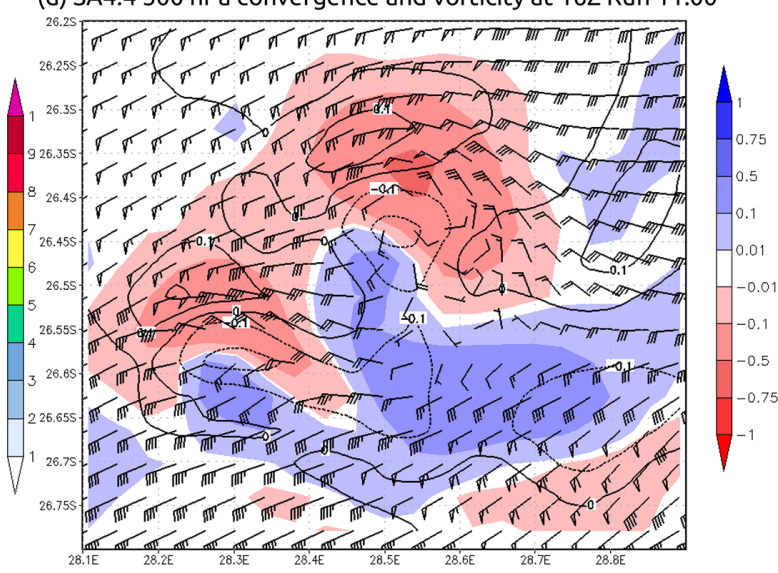

Figure 15. The 16:00 UTC SA4.4 analysis of the (a) $800 \mathrm{hPa}$ and (b) $500 \mathrm{hPa}$ convergence/divergence (in $10^{-2} \mathrm{~s}^{-1}$ ) at contour intervals of $0.1 \times 10^{-2} \mathrm{~s}^{-1}$ and specific humidity (in $\mathrm{g} \mathrm{kg}^{-1}$ ) at shaded fields of interval $1 \times \mathrm{g} \mathrm{kg}^{-1}$. Panel (c) indicates $10 \mathrm{~m}$ convergence/divergence contour fields (in $10^{-2} \mathrm{~s}^{-1}$ ) at $0.1 \times 10^{-2} \mathrm{~s}^{-1}$ intervals and wind barbs and wind magnitude shades (in kn) at $10 \mathrm{kn}$ intervals. Panel (d) indicates $500 \mathrm{hPa}$ convergence/divergence (in $10^{-2} \mathrm{~s}^{-1}$ ) at contour intervals of $0.1 \times 10^{-2} \mathrm{~s}^{-1}$ and vorticity (in $10^{-2} \mathrm{~s}^{-1}$ ) shaded fields.

Future investigations will involve experimental research over the Highveld region of South Africa to understand mesoscale and local dynamics processes responsible for tornadogenesis in some severe storms. Such a study, to the best of our knowledge, has never been conducted. This will help improve representation of regional and local processes in mesoscale NWP models which will in turn improve the skill of severe storm prediction over South Africa.

Data availability. The UM is licensed, and legal possibilities of accessing its operational data should be cleared with the SAWS. Radiosonde data can be obtained from the Integrated Global Radiosonde Archive Version 2 (IGRA 2) via https://doi.org/10.1175/JTECH-D-17-0223.1 (Durre et al., 2018). Radar and weather station data can be obtained from the SAWS. ERA5 data can be obtained from Copernicus Climate Change Service Climate Data Store via https://climate.copernicus. eu/climate-reanalysis (Hersbach and Dee, 2016).
Author contributions. LEL and MJMB conceived and designed the study. LEL, TGR, MJMB, PM, and TN performed the analysis while continuously discussing results with all authors, who in turn contributed through their feedback. TGR, MG, LEL, and NM curated the data. LEL wrote the initial draft of the manuscript, with all authors reviewing and contributing in various proportion to sections. All authors edited the final draft and provided significant comments and suggestions for further clarity and improvements.

Competing interests. The authors declare that they have no conflict of interest.

Acknowledgements. The authors thank the SAWS for providing model and observational data for this study. This work was partially supported through the Climate Research for Development (CR4D) Fellowship implemented by the African Academy of Sciences (AAS) in partnership with the United Kingdom's Department for International Development (DfID) Weather and Climate Infor- 
mation Services for Africa (WISER) programme and the African Climate Policy Centre (ACPC) of the United Nations Economic Commission for Africa (UNECA). The authors also acknowledge the SAWS for supporting this study.

Financial support. This research has been supported by the African Academy of Sciences (grant no. CR4D-19-11).

Review statement. This paper was edited by Johannes Dahl and reviewed by two anonymous referees.

\section{References}

Adger, W. N., Huq, S., Brown, K., Conway, D., and Hulme, M.: Adaptation to climate change in the developing world, Prog. Dev. Stud., 3, 179-195, https://doi.org/10.1191/1464993403ps060oa, 2003.

Awojobi, O. N. and Tetteh, J.: The impacts of climate change in Africa: A review of the scientific literature, J. Interdiscip. Multidiscip. Res., 5, 39-52, 2017.

Banacos, P. C. and Schultz, D. M.: The use of moisture flux convergence in forecasting convective initiation: Historical and operational perspectives, Weather Forecast., 20, 351-366, https://doi.org/10.1175/WAF858.1, 2005.

Bauer, P., Thorpe, A., and Brunet, G.: The quiet revolution of numerical weather prediction, Nature, 525, 47-55, https://doi.org/10.1038/nature14956, 2015.

Boko, M., Niang, I., Nyong, A., Vogel, C., Githeko, A., Medany, M., Osman-Elasha, B., Tabo, R. and Yanda, P.: Africa. Climate Change 2007: Impacts, Adaptation and Vulnerability. Contribution of Working Group II to the Fourth Assessment Report of the Intergovernmental Panel on Climate Change,edited by: Parry, M. L., Canziani, O. F., Palutikof, J. P., van der Linden, P. J., and Hanson, C. E., Cambridge University Press, Cambridge, UK, 433467, 2007.

Bryan, G., Wyngaard, J., and Fritsch, J.: Resolution Requirements for the Simulation of Deep Moist Convection, Mon. Weather Rev., 131, 2394-2416, 2003.

Carley, M. and Bustelo, E.: Social indicators and development, Proj. Apprais., 1, 266-268, https://doi.org/10.1080/02688867.1986.9726580, 1986.

Clark, P., Roberts, N., Lean, H., Ballard, S. P., and CharltonPerez, C.: Convection-permitting models: a step-change in rainfall forecasting, Meteorol. Appl., 23, 165-181, https://doi.org/10.1002/met.1538, 2016.

Craven J. P. and Brooks, H. E.: Baseline climatology of soundingderived parameters associated with deep moist convection, Natl. Weather Dig., 28, 13-24, 2004.

Cressman, G. P.: An operational objective analysis system, Mon. Weather Rev., 87, 367-374, https://doi.org/10.1175/15200493(1959)087<0367:AOOAS>2.0.CO;2, 1959.

Dahl, J. M. L.: Tilting of horizontal shear vorticity and the development of updraft rotation in supercell thunderstorms, J. Atmos. Sci., 74, 2997-3020, https://doi.org/10.1175/JAS-D-17-0091.1, 2017.
Davies, T., Cullen, M. J. P., Malcolm, A. J., Mawson, M. H., Staniforth, A., White, A. A., and Wood, N.: A new dynamical core for the Met Office's global and regional modeling of the atmosphere, Q. J. Roy. Meteor. Soc., 131, 1759-1782, https://doi.org/10.1256/qj.04.101, 2005.

Davies-Jones, R.: A review of supercell and tornado dynamics, Atmos. Res., 158, 274-291, https://doi.org/10.1016/j.atmosres.2014.04.007, 2015.

Davies-Jones, R., Trapp, R. J., and Bluestein, H. B.: Tornadoes and tornadic storms, chap. 5, Meteorol. Monogr., 28, 167-221, https://doi.org/10.1007/978-1-935704-06-5_5, 2001.

Davis, C. A., Brown, B. G., Bullock, R., and Halley-Gotway, J.: The Method for Object-Based Diagnostic Evaluation (MODE) Applied to Numerical Forecasts from the 2005 NSSL/SPC Spring Program, Weather Forecast., 24, 1252-1267, https://doi.org/10.1175/2009WAF2222241.1, 2009.

Davis-Reddy, C. L. and Vincent, K.: Climate risk and vulnerability: A handbook for southern Africa, 2nd ed., CSIR, Pretoria, South Africa, 2017.

DEA: Long-Term Adaptation Scenarios Flagship Research Programme for South Africa: Summary for Policy-Makers, Department of Environmental Affairs, Pretoria, South Africa, 2016.

Doswell, C. A. and Burgess, D. W.: On some issues of United States tornado climatology, Mon. Weather Rev., 116, 495-501, https://doi.org/10.1175/1520 0493(1988)116<0495:OSIOUS>2.0.CO;2, 1988.

Durre, I., Yin, X., Vose, R. S., Applequist, S., and Arnfield, J.: Enhancing the data coverage in the integrated global radiosonde archive, J. Atmos. Ocean. Tech., 35, 1753-1770, https://doi.org/10.1175/JTECH-D-17-0223.1, 2018.

EASAC: Extreme weather events in Europe: Preparing for climate change adaptation: an update on EASAC's 2013 study, EASAC, Teutschenthal, Germany, 1-8, 2018.

Engelbrecht, C. J., Engelbrecht, F. A., and Dyson, L. L.: Highresolution model-projected changes in mid-tropospheric closedlows and extreme rainfall events over southern Africa, Int. J. Climatol., 33, 173-187, https://doi.org/10.1002/joc.3420, 2013.

Gijben, M.: The lightning climatology of South Africa, S. Afr. J. Sci., 108, 1-10, https://doi.org/10.4102/sajs.v108i3/4.740, 2012.

Gilleland, E., Ahijevych, D., Brown, B. G., Casati, B., and Ebert, E. E.: Intercomparison of Spatial Forecast Verification Methods. Weather Forecast., 24, 1416-1430, https://doi.org/10.1175/2009WAF2222269.1., 2009.

Glickman, T. S. (Ed.): Glossary of Meteorology, 2nd ed., American Meteorological Society, Boston, 2000.

Goliger, A. M. and Retief, J. V.: Severe wind phenomena in Southern Africa and the related damage, J. Wind. Eng. Ind. Aerodyn., 95, 1065-1078, https://doi.org/10.1016/j.jweia.2007.01.029, 2007.

Hamill, T.m., Schneider, R. S., Brooks, H. E., Forbes, G. S., Bluestein, H. B., Steinberg, M., Melendez, D., and Dole, R. M.: The May 2003 extended tornado outbreak, B. Am. Meteorol. Soc., 86, 531-542, https://doi.org/10.1175/BAMS-86-4-531, 2005.

Hand, W. H. and Cappelluti, G.: A global hail climatology using the UK Met Office convection diagnosis procedure (CDP) and model analyses, Meteorol. Appl., 18, 446-458, 2011.

Handmer, J., Honda, Y., Kundzewicz, Z. W., Arnell, N., Benito, G., Hatfield, J., Mohamed, I. F., Peduzzi, P., Wu, S., Sherstyukov, B., 
Takahashi, K., and Yan, Z.: Changes in impacts of climate extremes: human systems and ecosystems, in: Managing the Risks of Extreme Events and Disasters to Advance Climate Change Adaptation, edited by: Field, C. B., Barros, V., Stocker, T. F., Qin, D., Dokken, D. J., Ebi, K. L., Mastrandrea, M. D., Mach, K. J., Plattner, G.-K., Allen, S. K., Tignor, M., and Midgley, P. M., A Special Report of Working Groups I and II of the Intergovernmental Panel on Climate Change (IPCC), Cambridge University Press, Cambridge, UK, and New York, NY, USA, 231-290, 2012.

Hart, N. C. G., Reason, C. J. C., and Fauchereau, N.: Cloud bands over southern Africa: seasonality, contribution to rainfall variability and modulation by the MJO, Clim. Dynam., 41, 11991212, https://doi.org/10.1007/s00382-012-1589-4, 2013.

Helmus, J. J. and Collis, S. M.: The Python ARM Radar Toolkit (Py-ART), a Library for Working with Weather Radar Data in the Python Programming Language, J. Open Res. Softw., 4, e25, https://doi.org/10.5334/jors.119, 2016.

Hersbach, H. and Dee, D.: ERA5 reanalysis is in production, ECMWF Newsletter, 147, 7, available at: https:// climate.copernicus.eu/climate-reanalysis (last access: 14 February 2019), 2016.

Holton, J. R. and Hakim, G. J.: An Introduction to Dynamic Meteorology, 5th ed., Academic Press, San Diego, https://doi.org/10.1016/B978-0-12-384866-6.00001-5, 2013.

Houze, R. A.: Cloud Dynamics, Academic Press, San Diego, 1993. Huffman, G. J., Stocker, E. F., Bolvin, D. T., Nelkin, E. J., Tan, T.: GPM IMERG Final Precipitation L3 1 day 0.1 degree $\times 0.1$ degree V06, Edited by Andrey Savtchenko, Goddard Earth Sciences Data and Information Services Center (GES DISC), Greenbelt, MD, https://doi.org/10.5067/GPM/IMERGDF/DAY/06, 2019.

IPCC: Climate Change 2014: Impacts, Adaptation, and Vulnerability. Part A: Global and Sectoral Aspects. Contribution of Working Group II to the Fifth Assessment Report of the Intergovernmental Panel on Climate Change, edited by: Field, C. B., Barros, V. R., Dokken, D. J., Mach, K. J., Mastrandrea, M. D., Bilir, T. E., Chatterjee, M., Ebi, K. L., Estrada, Y. O., Genova, R. C., Girma, B., Kissel, E. S., Levy, A. N., MacCracken, S., Mastrandrea, P. R., and White, L. L., Cambridge University Press, Cambridge, United Kingdom and New York, NY, USA, 1132, 2014.

Keat, W. J., Stein, T. H. M., Phaduli, E., Landman, S., Becker, E., Bopape, M-J. M., Hanley, K. E., Lean, H. W., and Webster, S.: Convective initiation and storm life cycles in convectionpermitting simulations of the Met Office Unified Model over South Africa, Q. J. Roy. Meteor. Soc., 145, 1323-1336, https://doi.org/10.1002/qj.3487, 2019.

Kruger, A. C. and Nxumalo, M. P.: Historical rainfall trends in South Africa: 1921-2015, Water SA, 43, 285-297, https://doi.org/10.4314/wsa.v43i2.12, 2017.

Malherbe, J., Engelbrecht, F. A., and Landman, W. A.: Projected changes in tropical cyclone climatology and landfall in the Southwest Indian Ocean region under enhanced anthropogenic forcing, Clim, Dynam., 40, 2867-2886, https://doi.org/10.1007/s00382-012-1635-2, 2013.

Markowski, P. M. and Richardson, Y. P.: Tornadogenesis: Our current understanding, forecasting considerations, and questions to guide future research, Atmos. Res., 93, 3-10, https://doi.org/10.1016/j.atmosres.2008.09.015, 2009.
Mashaba, S. and ANA reporter: WATCH: Night of horror as tornado hits Vaal Marina, IOL, 13 December 2017, available at: https://www.iol.co.za/news/south-africa/gauteng/ watch-night-of-horror-as-tornado-hits-vaal-marina-12392994 (last access: 21 August 2018), 2017.

Meehl, G. A., Karl, T., Easterling, D. R., Changnon, S., Pielke Jr., R., Changnon, D., Evans, J., Groisman, P., Knutson, T. R., Kunkel, K. E., Mearns, L. O., Parmesan, C., Pulwarty, R., Root, T., Sylves, R. T., Whetton, P., and Zwiers, F.: An introduction to trends in extreme weather and climate events: Observations, socioeconomic impacts, terrestrial ecological impacts, and model projections, B. Am. Meteorol. Soc., 81, 413-416, https://doi.org/10.1175/15200477(2000)081<0413:AITTIE>2.3.CO;2, 2000.

Melillo, J. M., Richmond, T. C., and Yohe, G. W. (Eds.): Climate Change Impacts in the United States: The Third National Climate Assessment, US Global Change Research Program, U.S. Government Printing Office, Washington, DC 841, https://doi.org/10.7930/J0Z31WJ2, 2014.

Mirza, M. M. Q.: Climate change and extreme weather events: can developing countries adapt?, Clim. Policy, 3, 233-248, https://doi.org/10.1016/S1469-3062(03)00052-4, 2003.

Mitchley, A.: PICS: Over 30 injured, 300 homes damaged as tornado tears through Vaal Marina, News24, 12 December 2017, available at: https://www.news24.com/SouthAfrica/News/picsover-30-injured-300-homes-damaged-as-tornado-tears-throughvaal-marina-20171212 (last access: 21 August 2018), 2017.

Ndarana, T, Mpati, S., Bopape, M-J. M., Engelbrecht, F., and Chikoore, H.: The flow and moisture fluxes associated with ridging South Atlantic Ocean anticyclones during the subtropical southern African summer, Int. J. Climatol., 41, E1000- E1017, https://doi.org/10.1002/joc.6745, 2021.

NDMC: Annual Report 2017/2018, National Disaster Management Centre, Pretoria, South Africa, 2018.

Nuttall, M.: Protecting the Arctic: Indigenous Peoples and Cultural Survival, 195, Routledge, London, 1998.

Rae, K. J.: A modified Supercell Composite Parameter for supercell thunderstorms over the Gauteng Province, South Africa, Masters Dissertation, University of Pretoria, South Africa, 2014.

Randall, D., Khairoutdinov, M., Arakawa, A., and Grabowski, W.: Breaking the cloud parameterization deadlock, B. Am. Meteorol. Soc., 84, 1547-1564, https://doi.org/10.1175/BAMS-84-111547, 2003.

Randall, D., DeMott, C., Stan, C., Khairoutdinov, M., Benedict, J., McCrary, R., Thayer-Calder, K., and Branson, M.: Simulations of the Tropical General Circulation with a Multiscale Global Model, Meteor. Monogr., 56, 15.1-15.15, https://doi.org/10.1175/AMSMONOGRAPHS-D-15-0016.1, 2016.

Reason, C. J. C. and Keibel, A.: Tropical cyclone Eline and its unusual penetration and impacts over the Southern African mainlands, Weather Forecast., 19, 789-805, https://doi.org/10.1175/15200434(2004)019<0789:TCEAIU>2.0.CO;2, 2004.

Roberts, N.: Assessing the spatial and temporal variation in the skill of precipitation forecasts from an NWP model, Meteorol. Appl., 15, 163-169, https://doi.org/10.1002/met.57, 2008.

SABC: Midvaal residents affected by tornado to be housed at churches and community centres, SABC, 12 December 2017, 
available at: https://www.youtube.com/watch?v=dXcPFF11TIg (last acess: 21 August 2018), 2017.

Sansom, H. W.: The occurrence and distribution of hail in Africa, Meteorol. Mag., 95, 212-218, 1966.

SAWS: Climate Summary of South Africa, South African Weather Service, 28, 1-5, 2018.

Seko, H., Kunii, M., Yokota, S., Tsuyuki, T., and Miyoshi, T.: Ensemble experiments using a nested LETKF system to reproduce intense vortices associated with tornadoes of 6 May 2012 in Japan, Prog. Earth Planet. Sci., 2, 42, https://doi.org/10.1186/s40645-015-0072-3, 2015.

Stein, T. H. M., Keat, W., Maidment, R. I., Landman, S., Becker, E., Boyd, D. F. A., Bodas-Salcedo, A., Pankiewicz, G., and Webster, S.: An Evaluation of Clouds and Precipitation in ConvectionPermitting Forecasts for South Africa, Weather Forecast., 34, 233-254, https://doi.org/10.1175/WAF-D-18-0080.1, 2019.

Stevens, D. E. and Crum, F. X.: Meteorology, Dynamic (Troposphere). Encyclopedia of Physical Science and Technology, edited by: Meyers, R. A., 3rd Ed., Academic Press, San Diego, 629-659, https://doi.org/10.1016/B0-12-2274105/00436-1, 2003.

Storm Report SA: Photos taken by Celestine Lourens of the tornado and damage in Vaal Marina today!, Storm Report SA, 11 December 2017, available at: https://www.facebook.com/ stormreportsaOFFICIAL/posts/1603665363029458 (last access: 21 August 2018), 2017.

Tyson, P. D. and Preston-Whyte, R. A.: The Weather and Climate of Southern Africa, 2nd ed., Oxford University Press, Cape Town, 396, 2000

UN: The Least Developed Countries Report 2018, United Nations Publications, New York, 159, 2018a.

UN: World Economic Situation and Prospects 2018, United Nations Publication, New York, 187, 2018b.
Walters, D., Boutle, I., Brooks, M., Melvin, T., Stratton, R., Vosper, S., Wells, H., Williams, K., Wood, N., Allen, T., Bushell, A., Copsey, D., Earnshaw, P., Edwards, J., Gross, M., Hardiman, S., Harris, C., Heming, J., Klingaman, N., Levine, R., Manners, J., Martin, G., Milton, S., Mittermaier, M., Morcrette, C., Riddick, T., Roberts, M., Sanchez, C., Selwood, P., Stirling, A., Smith, C., Suri, D., Tennant, W., Vidale, P. L., Wilkinson, J., Willett, M., Woolnough, S., and Xavier, P.: The Met Office Unified Model Global Atmosphere 6.0/6.1 and JULES Global Land 6.0/6.1 configurations, Geosci. Model Dev., 10, 14871520, https://doi.org/10.5194/gmd-10-1487-2017, 2017.

Weisman, M., Skamarock, W., and Klemp, J.: The Resolution Dependence of Explicitly Modeled Convective Systems, Mon. Weather Rev., 125, 527-548, 1997.

WMO: Reducing Vulnerability to Extreme Hydro-Meteorological Hazards in Mozambique After Cyclone IDAI, World Meteorological Organisation, Geneva, 64, available at: https://library. wmo.int/doc_num.php?explnum_id=6259 (last access: 21 July 2020), 2019.

Wood, N., Staniforth, A., White, A., Allen, T., Diamantakis, M., Gross, M., Melvin, T., Smith, C., Vosper, S., Zerroukat, M., and Thuburn, J.: An inherently mass-conserving semi-implicit semiLagrangian discretization of the deep-atmosphere global nonhydrostatic equations, Q. J. Roy. Meteor. Soc., 140, 1505-1520, https://doi.org/10.1002/qj.2235, 2014.

Yokota, S., Seko, H., Kunii, M., Yamauchi, H., and Niino, H.: The tornadic supercell on the Kanto Plain on 6 May 2012: Polarimetric radar and surface data assimilation with EnKF and ensemblebased sensitivity analysis, Mon. Weather Rev., 144, 3133-3157, https://doi.org/10.1175/MWR-D-15-0365.1, 2016. 